\title{
CMPO
}

THE CENTRE FOR MARKET AND PUBLIC ORGANISATION

\section{The Captain of the Men of Death and His Shadow: Long-Run Impacts of Early Life Pneumonia Exposure}

\author{
Sonia Bhalotra and Atheendar Venkataramani
}

October 2011

Working Paper No. 11/273

\author{
Centre for Market and Public Organisation \\ Bristol Institute of Public Affairs \\ University of Bristol \\ 2 Priory Road \\ Bristol BS8 1TX \\ http://www.bristol.ac.uk/cmpo/
}

Tel: (0117) 3310952

Fax: (0117) 3310705

E-mail:cmpo-admin@bristol.ac.uk

The Centre for Market and Public Organisation (CMPO) is a leading research centre, combining expertise in economics, geography and law. Our objective is to study the intersection between the public and private sectors of the economy, and in particular to understand the right way to organise and deliver public services. The Centre aims to develop research, contribute to the public debate and inform policy-making.

CMPO, now an ESRC Research Centre was established in 1998 with two large grants from The Leverhulme Trust. In 2004 we were awarded ESRC Research Centre status, and CMPO now combines core funding from both the ESRC and the Trust.

ISSN 1473-625X 


\title{
The Captain of the Men of Death and His Shadow: Long-Run Impacts of Early Life Pneumonia Exposure
}

\author{
Sonia Bhalotra ${ }^{1}$ \\ and \\ Atheendar Venkataramani ${ }^{2}$ \\ ${ }^{1} \mathrm{CMPO}$, University of Bristol \\ ${ }^{2}$ Department of Medicine, Massachusetts General Hospital
}

October 2011

\begin{abstract}
We exploit the introduction of sulfa drugs in 1937 to identify the causal impact of exposure to pneumonia in infancy on later life well-being and productivity in the United States. Using census data from 1980-2000, we find that cohorts born after the introduction of sulfa experienced increases in schooling, income, and the probability of employment, and reductions in disability rates. These improvements were larger for those born in states with higher pre-intervention levels of pneumonia as these were the areas that benefited most from the availability of sulfa drugs. These estimates are, in general, larger and more robust to specification for men than for women. With the exception of cognitive disability and poverty for men, the estimates for African Americans are smaller and less precisely estimated than those for whites. This is despite our finding that African Americans experienced larger absolute reductions in pneumonia mortality after the arrival of sulfa. We suggest that pre-Civil Rights barriers may have inhibited their translating improved endowments into gains in education and employment.
\end{abstract}

Keywords: early childhood, infectious diseases, pneumonia, medical innovation, antibiotics, schooling, income, disability, mortality trends.

JEL Classification: I18, H41

Electronic version: www.bristol.ac.uk/cmpo/publications/papers/2011/wp273.pdf

\section{Acknowledgements}

We would like to thank Douglas Almond, Tania Barham, Alan Barreca, Prashant Bharadwaj, Alfredo Burlando, Janet Currie, Jason Fletcher, Winnie Fung, Caroline Hoxby, Adriana Lleras-Muney, Alice Mesnard and Michael Rothschild for helpful comments. We are grateful to Anne Case, Adriana Lleras-Muney, and Grant Miller for providing access to their historical US data, Sarah Karlsberg-Schaffer for research assistance in extending this historical database and Eddy Tam for his excellent comments and his expert help with the data. All errors are our own. We have benefited from presenting earlier versions of this work at the 2010 American Society of Health Economics conference and at the following events in 2011: the American Economics Association Meeting, the NBER Children's Meeting, the UK launch meeting of Academics Stand Against Poverty, the University of Florence, conferences held at DIAL Paris and DIW Berlin and at the CAGE research centre at Warwick, the Health and Human Capital workshop in Mannheim and the European Association of Labour Economics conference. Forthcoming this term are seminars at the Wellcome Trust Unit for the Study of the History of Medicine, the Centre for the Study of African Economies and the Health Economics Research Centre, all at Oxford University.

\section{Address for correspondence}

CMPO, Bristol Institute of Public Affairs

University of Bristol

2 Priory Road

Bristol BS8 1TX

s.bhalotra@bristol.ac.uk

www.bristol.ac.uk/cmpo/ 


\section{Introduction}

Infections are the leading cause of child mortality in developing countries, as they were in developed nations until the middle of the 20th century (Cohen, 2000; Black et al., 2010). While this is well established, there is relatively limited (causal) evidence of the impact of infectious disease on survivors. Recent epidemiological studies suggest mechanisms by which exposure to infectious disease in early childhood may generate long run impacts. In essence, infection generates an inflammatory immune response that diverts nutritional resources away from physical and mental development. In this way, severe or repeated infections can directly lead to long-term "scarring" in the form of poorer health and lower cognitive development in adulthood (Crimmins and Finch, 2004; Crimmins and Finch, 2006b; Eppig et al., 2010). In addition, if there are dynamic complementarities in early age inputs (Cunha and Heckman, 2007; Glewwe and Miguel, 2008), and if parents tend to reinforce changes in early life endowments, any particular damage in infancy may translate into multiplicative deficits later in childhood and into adulthood. These processes suggest that wellbeing and productivity in today's population may, to a degree, have their roots in disease and treatment conditions that prevailed a generation or more ago.

This paper investigates whether early life, in particular birth year, exposure to pneumonia has impacts on disability, human capital and productivity in adulthood. The setting is early $20^{\text {th }}$ century America, when pneumonia accounted for 1 of every 10 deaths and, barring mortality from premature birth, was the leading cause of infant mortality (Linder and Grove, 1947; Wegman, 2001). The ubiquity and ruthlessness of the disease led the great physician Sir William Osler to coin pneumonia as the "Captain of the Men of Death." The Captain reigns in today's developing countries, with pneumonia being the dominant cause of childhood mortality, accounting for 20 to 30 per cent of under- 5 deaths, two thirds of which occur in infancy (Bhutta, 2007; Black et al., 2010). It is estimated that pneumonia kills 1.6 million children every year - more than AIDS, malaria and tuberculosis combined (World Health Organization, 2010). ${ }^{1}$ We study birth year exposure in view of evidence that morbidity and mortality from pneumonia were far more prevalent in infancy

\footnotetext{
${ }^{1}$ Yet AIDS, malaria and tuberculosis have generally commanded more attention from global health experts and policymakers. For example, the World Health Organization Commission on Macroeconomics and Health chaired by Jeffrey Sachs made the case for a Global Health Fund to fight these diseases. Pneumonia has more recently commanded public policy attention. This is discussed further in the Conclusions of the paper.
} 
than at any other age. Moreover, infancy is a time when growth is rapid, nutritional demands are high, and developmental plasticity is greatest. For these reasons, exposure in the birth year is most likely to create irreversible damage.

Identification of causal effects of early life infections on later life attainments is challenged by likely selectivity into infection. We overcome this problem by investigating the impacts of declines in pneumonia driven by the arrival of sulfonamide antibiotics (sulfa drugs) in 1937. These agents were the first clinically available antibiotics and were quickly utilized to treat a variety of potentially fatal bacterial infections. Their arrival was responsible for sharp decreases in morbidity and mortality from pneumonia (Greengard et al., 1943; Lesch, 2007; Jayachandran et al., 2010). Together with the quasi-experimental cohort variation generated by the sudden and plausibly exogenous arrival of sulfa drugs, our research strategy exploits the fact that states most burdened by pneumonia in the pre-sulfa era experienced the largest declines upon the introduction of sulfa. We investigate whether this short-run pattern of sudden convergence starting in 1937/38 is mirrored in longer run outcomes such as education, income, employment and disability recorded for sulfa cohorts in Unites States census data for 1980-2000. Our identification of causal effects is further strengthened by our use of variation across diseases in their sensitivity to sulfa drugs and variation across age in susceptibility to pneumonia.

Our core findings are that cohorts exposed to sulfa drugs and thereby less pneumonia in the birth year, achieved large improvements in schooling, employment and income and lower risks of disability and poverty in adulthood. Importantly, these effects are largest for individuals born in states with high pre-intervention pneumonia mortality rates, consistent with their gaining more from the new antibiotics. The estimated gains for men are larger in magnitude and more robust to specification than for women. This is not an uncommon finding in the early childhood shocks literature (Stein et al., 2003; Crimmins and Finch, 2006a; van der Berg et al., 2007; Banerjee et al., 2010; Almond and Mazumder, 2011).

The results are robust to controls for state-specific trends in health and education infrastructure, public health spending, income and a range of communicable and noncommunicable diseases that were not responsive to sulfa drugs. They are also robust to controlling for maternal mortality, which declined sharply after 1937 as a result of the sulfa drug revolution (Thomasson and Treber, 2008; Jayachandran et al., 2010). Using a more flexible specification that allows for differential impacts by age of exposure, we do not find 
any noteworthy long run health or socioeconomic gains from reductions in pneumonia for cohorts born before 1937, who were at least a year old when sulfa drugs were first introduced. This is consistent with the epidemiology of pneumonia. We also conduct a variety of other robustness checks, including a triple difference specification exploiting the age distribution of pneumonia, a placebo intervention, changes in the cohort window used in estimation, and assessing the role of selective migration. Our substantive conclusions hold up nicely to this slew of falsification checks.

Since pneumonia infections were twice as prevalent amongst the poor as among the rich (Britten, 1942), our findings suggest that the narrowing of early life health inequalities induced by sulfa drugs led to a narrowing of socioeconomic inequalities half a century later. This complements evidence of the causality in the reverse direction, running from socioeconomic inequalities to health inequalities (Glied and Lleras-Muney, 2008). It suggests mechanisms that cycle into one another and hold the potential to generate intergenerational impacts to the extent that healthier children grow up to be richer adults and richer adults are better able to invest in the health of their offspring. Our estimates also establish that early life health improvements generate increased productivity.

The gains we identify are not evenly distributed by race. Post-sulfa drug African American cohorts show large, significant reductions in cognitive disability and poverty risk as adults, but no evidence of improvements in schooling or employment. We show that this is despite their having experienced larger absolute reductions in infant pneumonia upon the arrival of sulfa drugs ${ }^{2}$. We reconcile these findings by positing that blacks faced more limited opportunities and incentives to translate their improved physical and mental endowments into human capital in the pre-Civil Rights Era. Put differently while blacks experienced improvements in endowments that translated to a lower risk of poverty later in life, this did not occur through investments in formal schooling or training, presumably because of low returns to such investments in an era when blacks faced poor schools and low wage returns

\footnotetext{
2 As we discuss later, this evidence contrasts with previous work which suggests that blacks may have had more limited access to sulfa drugs S. Jayachandran, A. Lleras-Muney and K. V. Smith (2010), 'Modern Medicine and the 20th-Century Decline in Mortality: Evidence on the Impact of Sulfa Drugs', American Economic Journal: Applied Economics 2(2): 118-146. in line with racial segregation in hospital access D. Almond, K. Chay and M. Greenstone (2006), 'Civil Rights, the War on Poverty, and Black-White Convergence in Infant Mortality in the Rural South and Mississippi', MIT Department of Economics.. We suggest that the widespread outpatient use of sulfa drugs (estimated at $70 \%$; see section 2), which were also relatively inexpensive, limits the importance of barriers to hospital care.
} 
to education. This underlines the importance of political and social institutions in mediating long run impacts of early life shocks. It contributes to debates regarding the origins of contemporary race gaps in test-scores and educational attainment (Chay et al., 2009), underlining the complementarity of early life health with human capital investments, a theme that is familiar from (Cunha and Heckman, 2007) but that relies upon what is still a limited evidence base.

Our research relates more generally to two independently flowing streams of the literature. One is the debate regarding the causes of underdevelopment, which remains unsettled on the question of how much health contributes to productivity (Gallup and Sachs, 2001; Acemoglu and Johnson, 2007). The other concerns the origins of socioeconomic inequality in early childhood. Large tracts of this literature focus upon the influence of parental resources and attitudes on investments in children (Black et al., 2007; Cunha and Heckman, 2009). This paper contributes to an emerging strand that focuses upon the importance of early life health (Currie, 2009; Almond and Currie, 2011). Evidence pertaining to the benefits of investments in child health is clearly of huge relevance in today's poor countries, but there is a scarcity of consistent causal evidence (Glewwe and Miguel, 2008).

Some previous studies examine persistent impacts of infectious disease, for example, (Costa, 2005; Bozzoli et al., 2009; Case and Paxson, 2010). Cleaner identification is afforded in studies that exploit natural or policy experiments. In a seminal study (Almond, 2006) identifies long run effects of in utero exposure to influenza pandemics; also see (Kelly, 2009). We contribute to recent work that investigates the impact of public interventions, the policy implications of which are clearer. Earlier studies have focused upon childhood exposure to malaria eradication (Bleakley, 2010; Cutler et al., 2010; Lucas, 2010; Venkataramani, 2010) or deworming (Baird et al., 2011).

We advance the literature in several ways. First, we provide the first estimates of the long-run sequelae of pneumonia, the public health importance of which was set out earlier. ${ }^{3}$ Second, we use a richer set of controls than many of the earlier studies. Third, we look at

${ }^{3}$ Using longitudinal data for the 1950-1980 birth cohorts in twelve OECD-member countries, Bozzoli et al. identify a significant impact of postneonatal mortality rate on adult height. They show that this is largely driven by pneumonia. In a longitudinal study of British men, Barker (1992) found that bronchitis, pneumonia, and whooping cough before age 5 are associated with reduced mean forced expiratory volume in one second (FEV1) at ages 59 to 70 . We use quasi-experimental data and extend these findings to consider other outcomes, importantly, including socioeconomic outcomes. 
changes in the disease environment of a scale that may plausibly be brought about by current day interventions in developing countries. In contrast, the pandemic conditions and (near)total eradication campaigns examined in previous studies are dramatic events. ${ }^{4}$ Fourth, our use of sulfa drugs as a source of identifying variation allows us to provide the first estimates of the long-run benefits of medical therapeutics. Our findings may therefore motivate investment in medical research and changes in extant patent laws and marketing structures to help promote the distribution of pharmaceuticals such as antibiotics at affordable prices in the developing world (this discussion is developed in the Conclusion).

The rest of the paper is laid out as follows. Section 2 discusses the sulfa drug revolution and its effects on pneumonia mortality and morbidity in the United States. Section 3 sets out our research strategy, and Section 4 describes the data. Section 5 presents the results and Section 6 discusses policy implications and concludes.

\section{Pneumonia and the Sulfa Drug Revolution}

We first describe the prevalence and distribution of pneumonia in the 1930s, underlining its contribution to overall mortality rates and its particularly high incidence in infancy. We then provide evidence of the sharp drop in pneumonia mortality and corresponding declines in morbidity that flowed from the introduction of sulfa drugs in 1937. We further show that this stimulated convergence in pneumonia rates across the US states.

Pneumonia is an inflammatory disease of the lungs largely caused by infectious agents such as bacteria and viruses. The symptoms of pneumonia include cough, shortness of breath, chest pain, and fever. There are several ways in which pneumonia may impact long-run health and socioeconomic outcomes. First, the inflammation associated with pneumonia requires energy, and infant exposure to the disease may divert nutrients from being used towards cognitive and physical development, which can lead to reduced cognition

\footnotetext{
${ }^{4}$ Influenza mortality increased four-fold during the flu epidemics analyzed while the sulfa-induced decline in pneumonia mortality rates was $17 \%$ (all ages: Jayachandran et al. 2010) to $30 \%$ (infantsour estimates). So, epidemic infection rates are some orders of magnitude larger than endemic rates. It may be that there is some threshold below which population level impacts are not discernible, making it difficult to generalize the results of pandemic infection studies to the case of more subtle interventions in the disease environment such as associated with health campaigns, clean water programs or the distribution of medicines.
} 
and worse health later in life $\mathrm{f}^{5}$. The consequences of this metabolic cost are likely decreasing in age: for example, infants expend some $87 \%$ of their metabolic energy in brain development (compared to $25 \%$ in adults), leaving them more vulnerable to scarring (Eppig et al., 2010). Second, inflammation is associated with a loss of appetite, which leads to reduced nutritional intake during a time when it is needed most. Third, lung architecture develops in utero and in the first three years of life (Shaheen, 1997): it seems plausible that early lung damage has persistent effects on more general development. It may also reduce the capacity to play, learn and work, all of which have socioeconomic consequences. Finally, any direct physiological damage is likely to be reinforced by reduced human capital investments both because of dynamic complementarities and because the reward to these investments is increasing in life expectancy.

In the 1930s, pneumonia accounted for $10 \%$ of all-age deaths in the United States and about $44 \%$ of neonatal deaths. ${ }^{6}$ The underlying incidence of pneumonia was high as well, though this is more difficult to pin down because of patchy and unreliable data. Estimates from the US National Health Survey of 1934-1936 show a nationwide morbidity rate of 3 cases per 100 infants, with rates twice as high among the poor and those living in crowded conditions (Britten, 1942). However, it is likely that this represents a significant (at least two-fold) underestimate of the true pneumonia burden (Klugman and Feldman, 2009). Indeed, pneumonia in the 1930s United States may have had a similar incidence and prevalence as it does in today's developing countries, where it is estimated that there are between 15 and 28 pneumonia cases per 100 children under the age of 4 each year (Rudan et al., 2004; Lopez et al., 2006).

Pneumonia, both then and now, preferentially attacks very young children and the elderly. Using data from the 1934-1936 National Health Survey, Britten (1942) illustrates that pneumonia morbidity was twice as high for infants as it was for 1-4 year olds, and nearly 10 times as high as for 10-15 year olds (Figure 1). Pneumonia was more prevalent in the US

\footnotetext{
${ }^{5}$ On the other hand, epidemiologists have suggested that brain sparing strategies operate in babies whereby neural development is prioritised over other aspects of growth in conditions of resource scarcity (Scherjon et al. 1996, Almond and Currie 2011), so the extent to which infection has cognitive impacts is an empirical question.

${ }^{6}$ Young children tend to be more vulnerable to contracting and sustaining infections such as pneumonia because their immune systems are underdeveloped. The all cause neonatal mortality rate per 1000 births in 1930 was 3.6 and mortality from pneumonia was 1.6. By 1940 these rates had dropped to 2.4 and 1.1 respectively.
} 
South and some parts of the West (Figure 2). This is consistent with the known risk factors for (bacterial) pneumonia (poverty, overcrowding, and poor nutrition) being relatively pressing issues in the poorer American South in the 1930s (Klugman and Feldman, 2009; van der Poll and Opal, 2009). As we discuss in the next section, our research strategy exploits this age and geographic variation.

Prior to the arrival of sulfa drugs, pneumonia was primarily treated with supportive care. In the early 1930s, a small but growing number of clinicians began to use intravenous serum therapy to combat bacterial pneumonia, which was often more severe and conferred a higher risk of death than its viral counterpart (Lesch, 2007). ${ }^{7}$ Serum therapy was an expensive and time-intensive process restricted to hospitalized patients. There is nevertheless some clinical evidence of its effectiveness in reducing pneumonia mortality rates (Finland, 1960).

The antibiotic properties of sulfonamides were first noted in 1932 by German chemists conducting experiments on textile dyes. Evidence of their anti-microbial potential was first published in 1935 and confirmed in clinical trials conducted in the following two years (Gibberd, 1937; Long and Bliss, 1937; Kiefer, 2001; Lesch, 2007; Jayachandran et al., 2010). A December 1936 New York Times article lauded the potential benefits of sulfa and, by early 1937, the drugs became widely available in the United States. They were relatively inexpensive and heavily promoted, leading to a "sulfa craze" that lasted until the arrival of the first penicillins in 1942-44.

The arrival of sulfa drugs represented a tremendous boon to clinicians treating pneumonia. The first sulfa agents, such as Prontosil, were only somewhat effective against Streptococcus pneumonaie, the agent responsible for the majority of bacterial pneumonias. However, in 1938, sulfapyridine (also known as M\&B 693), became available for clinical use. Clinical trials conducted soon after sulfapyridine became available showed striking reductions (of 50-70\%) in pneumonia case fatality rates among inpatients (Evans and Gaisford, 1938; Gaisford, 1939; Lesch, 2007). Within months after its introduction, the use of sulfapyridine for treating pneumonia became widespread.

\footnotetext{
7 This involved obtaining antibodies from animals that were infected with a specific microbe. Serum refers to the component of animal blood comprised of fluid and antibodies, which has to be separated from the cellular component. The serum was injected intravenously into human patients, where the antibodies from the animal would bind to the infectious agent and aid the endogenous immune response (Lesch, 2007).
} 
In addition to the benefits noted in small clinical trials, the arrival of sulfa drugs had large impacts on mortality from pneumonia at the population level. Using state and national time series data for the United States, Jayachandran, et al (2010) demonstrate structural breaks in the time series data for mortality from sulfa treatable diseases around the time the drugs first became available. They estimate that sulfa drugs led to a $17 \%$ decline in pneumonia mortality. The decline was larger, at 32\%, amongst infants (see footnote 3). Figure 3 , which plots the trend in national pneumonia mortality rates illustrates these findings nicely. Prior to the arrival of sulfa, pneumonia rates held steady which suggests that serotherapy had little impact on population level pneumonia mortality rates. The death rate began to drop in 1937 (though it still was higher than in the 1930-1935 period) and then fell sharply in 1938 and thereafter. This pattern is consistent with the arrival of sulfa drugs better suited to combat pneumococcal bacteria in 1938. Continued gains are consistent with increasing market penetration and diffusion of information and acceptability of the new drug. ${ }^{8}$

Figure 4 examines the state-specific post-sulfa absolute reduction in pneumonia mortality as a function of the pre-sulfa rate in the birth state. This shows convergence in pneumonia mortality across states after 1937, confirming our prior that states with a greater initial burden of disease from pneumonia gained more from the arrival of sulfa drugs.

Because our goal is to examine the long-run impacts of pneumonia exposure, it is important to explicitly examine the effects of sulfa drugs on pneumonia morbidity, as well as mortality, at the population level. If the advent of sulfa drugs only saved the lives of those with severe cases of pneumonia, our long-run impact estimates may simply reflect selection or composition effects. If sulfa therapy additionally reduced morbidity amongst survivors then our long run estimates will tend to capture scarring net of any selection.

There is, in fact, compelling evidence that sulfa drugs led to reductions in the severity of pneumonia episodes. With respect to hospitalized patients, a number of clinical trials on infants and children from the era cite rapid improvements in fever, mental status and other physical examination findings, illustrating that the average inpatient case of pneumonia was

\footnotetext{
${ }^{8}$ In the next section we explain that the data series plotted in Figures 2 and 3 is for influenza plus pneumonia as this is the category for which annual state series are available. The fluctuations in the series prior to 1937 are driven by influenza outbreaks (Jayachandran et al., 2010). In the next section we provide evidence that the drop in the combined series in 1937 is entirely on account of pneumonia, influenza having shown no change, at least not for babies.
} 
shorter in duration and followed a less severe course as a result of sulfa chemotherapy (Hodes et al., 1939; Smith and Nemir, 1939; Moody and Knouf, 1940; Greengard et al., 1943). Data on industrial workers illustrate a $20-30 \%$ reduction in the number of illness days after the arrival of sulfa drugs (Ungerleider et al., 1943). Along the same lines, comparisons of US Army experiences between the first and second World Wars suggest that sulfa drugs were instrumental in drastically reducing the severity of and infirmity time from pneumonia among soldiers. In addition, sulfa drugs were widely available to and utilized by laypersons and community physicians soon after their arrival in the US (Lesch, 2007). Thus, it is likely that pneumonias treated in the community - roughly $70 \%$ of all cases, according to Britten (1942) - would be less severe and shorter in duration than in the absence of antibiotic therapy and less likely to warrant hospitalization.

Regarding the incidence of pneumonia, in theory it is possible that antibiotic therapy would reduce the probability of contracting pneumonia since those undergoing treatment will produce fewer respiratory secretions and so be less contagious. However, the evidence is mixed. On the one hand, incidence rates in the sample of industrial workers alluded to above did not appear to decline once sulfa-drugs became available (Ungerleider et al., 1943). On the other, data from the Boston City Hospital suggest that pneumococcal bacteremia rates among hospitalized patients fell drastically after sulfa drugs became available (McGowan et al., 1975). Regardless, as measures of pneumonia incidence are sensitive to improvements in surveillance and diagnosis, it is difficult to draw firm conclusions from the available data. As such, while we can state confidently that sulfa drugs led to noteworthy reductions in the length, severity and risk of death from pneumonia, we do not have reliable evidence on whether they led to reductions in the probability of contracting the infection altogether. However, our research strategy accounts for contagion-related spillovers by virtue of estimating population-averaged impacts.

\section{Data}

Data for the outcome variables were taken from the 1980, 1990, and $20005 \%$ samples of the United States Census. The marginal cohort born around the time sulfa drugs first became available was 43,53 , and 63 years old at the time of each of these enumerations, respectively. We calculated means for each outcome by birth state, birth year, census year, race and gender and used the cell means in the analysis. Assessing impacts at the cell level allows us to account for cohort-level general equilibrium effects. To avoid measurement 
error, we dropped cells in the bottom $1 \%$ of the cohort size distribution (i.e., those with less than 50 persons), although our results are not sensitive to this.

The main outcomes we examine are years of schooling, logged household income, poverty status, employment status, and work limiting or preventing disability. These outcomes are available in all three censuses. In general, we use data from all three census waves as this improves the precision of our estimates. For schooling, we produced estimates using only the 1980 census to avoid duplicating the data given that years of schooling seldom change after the age of 43 (the age of the marginal sulfa cohort in our sample in 1980). We also analyse physical and cognitive disability which are only available in the 2000 census. The Data Appendix contains details and definitions and Appendix Table A1 presents descriptive statistics.

Data on all-age disease-specific mortality rates are from the US Vital Statistics and were gathered by Anne Case, Adriana Lleras-Muney and Grant Miller and supplemented by us. Information on the socioeconomic characteristics of states come from various sources (see Data Appendix). For the period of interest, state-level time series data on pneumonia mortality are aggregated with influenza mortality so we, like Jayachandran, et al (2010) work with this compound variable. Combining mortality rates from these causes may lower measurement error, given that surveillance systems may have conflated influenza and pneumonia deaths and a large portion of influenza deaths were caused by secondary bacterial pneumonia ${ }^{9}$

\section{Research Strategy}

Individuals who contract pneumonia are not a random draw from the population. For example, infection rates were higher in the US amongst the poor, rural residents, and African-Americans (Britten, 1942). So, even if disease exposure had no causal effects on later life attainments, we would likely observe that increased disease exposure in childhood was associated with lower socioeconomic status in adulthood. Since the nationwide arrival of sulfa drug technology was uncorrelated with individual and state level characteristics, we avoid this problem by exploiting the sharp cohort variation in pneumonia exposure (Figure 3)

\footnotetext{
${ }^{9}$ National level vital statistics data for the years 1930 and 1940 which disaggregate influenza and pneumonia among infants show that pneumonia accounted for the bulk of the joint pneumoniainfluenza category and that declines in pneumonia dominated the decline in the combined indicator. Amongst neonates, pneumonia declined from 1.6 to 1.1 per 1000 live births while influenza held steady at 0.2 . This is consistent with influenza, which is viral, being unresponsive to sulfa.
} 
along with the cross-state convergence in pneumonia burdens that it induced (Figure 4). Our baseline specification is:

$$
Y_{r s t c}=a+\beta^{*} \text { post }{ }_{t}^{*} \text { base_pneumonia } a_{s}+\delta_{s}+\zeta_{t}+\gamma_{r}+\mu_{c}+\theta_{r s}+\eta_{r t}+\lambda_{r c}+e_{r s t c}
$$

where $Y_{r s t}$ denotes an outcome recorded in adulthood for individuals of race $(r)$, birth state $(s)$ and birth year $(t)$ observed in census year $(c)$. The outcomes, listed earlier, are indicators either of human capital or of the returns to human capital. We define post $t_{t}=1$ for cohorts born in 1937, the year sulfa drugs were introduced and thereafter. The pre-sulfa pneumonia mortality rate in the birth state is denoted base_pneumonia and may be thought of as capturing treatment intensity. Infectious disease mortality rates are commonly used to proxy disease exposure; for a formalization of the rationale for this, see Bozzoli et al. (2008). Our research strategy is similar in spirit to that employed by (Acemoglu and Johnson, 2007; Bleakley, 2007; Lucas, 2010).

The Greek letters represent race-specific fixed effects for birth state, birth year and census year. As we discuss further below, we estimate every model separately by gender and some also by race. Standard errors are clustered at the birth state level to account for serial correlation in the outcomes (Bertrand et al., 2004). Regressions are weighted by cell size, although we note that the estimates are not sensitive to this. We restrict our analysis to the time period 1930-1943 in order to reduce the possibility of confounding from other public health events or interventions, for example, the influenza epidemic of 1928-9 and the increasingly widespread use of penicillin after 1943.

The estimated equation may be thought of as the reduced form of a system in which adult outcomes are allowed to depend upon pneumonia exposure at birth and the latter is instrumented with the sharp arrival of sulfa drugs, the impact of which varies across states as a function of their pre-sulfa pneumonia burden. The parameter $\beta$ will capture the full impact of sulfa-induced reductions in pneumonia exposure. This will include direct biological impacts of pneumonia infections on physiological growth including cognitive development in infancy and its impact on incentives to invest in human capital ${ }^{10}$.

${ }^{10}$ It will in principle also include any indirect impacts flowing, for example, from the increase in household resources generated by lower pneumonia morbidity amongst parents of the index cohort. 


\subsection{Unobserved heterogeneity at the birth state and birth year level}

The main threats to inference with the basic differences-in-differences sort of model above are unobservables that vary by birth state and birth year and are correlated with both pneumonia exposure in infancy and the outcomes. We therefore investigate sensitivity to a variety of controls for trends in health and socioeconomic conditions in the birth state.

Diseases Not Treatable by Sulfa Drugs: A particular concern is that post may pick up coincident factors other than sulfa drug availability that led to sudden improvements in health. A powerful check against this is to use information on trends in diseases that were not treatable with sulfa drugs. The premise is that omitted factors will not have discriminated between sulfa-treatable and sulfa-untreatable diseases. We interact post with pre-sulfa birth state specific mortality rates from tuberculosis, under-2 diarrhea, malaria, heart disease and cancer and include these as controls in our model. In this way we allow the outcomes to evolve as discontinuous functions of these five other diseases. Inclusion of the communicable diseases (tuberculosis, diarrhea, malaria) helps control for state specific changes in sanitation, public health programs, housing (etc) that may have coincided with the arrival of sulfa. For example, there were significant declines in malaria in this period (Barreca 2010). Controlling for malaria is likely to be particularly important to isolating the impact of pneumonia given that it, too, enjoyed a higher prevalence in the South and given the established potential of malaria to impact long-run outcomes (Barreca, 2010; Bleakley, 2010; Venkataramani, 2010). Including diarrhea, a disease of childhood, helps control for unobservables specific to the young. Inclusion of non-communicable diseases is expected to control for factors such as health care quality and access.

Diseases Treatable by Sulfa Drugs: Sulfa drugs led to marked declines in conditions other than pneumonia, most notably scarlet fever, erysipelas, meningitis and puerperal sepsis (Jayachandran et al. 2010). Thus, the coefficient on post* $t_{t}^{*}$ base_pneumonia may have loaded on to it the effects of reductions in (omitted) sulfa-treatable diseases. However, scarlet fever, erysipelas and meningitis accounted for a negligible fraction of infant mortality. In 1930, the number of infant deaths in 1000 live births from these diseases was $0.1,0.3$ and 0.2 compared with 8.9 from pneumonia.

Since pneumonia infections amongst adults of child-bearing age were relatively scarce (Figure 1), we expect the indirect effects to be small. 
In contrast, puerperal sepsis accounted for $40 \%$ of maternal deaths in 1930 and maternal mortality was high, at 7.03 deaths per 1000 births. Furthermore, maternal mortality rates fell sharply in 1937 (Thomasson and Treber, 2008; Jayachandran et al., 2010). To account for this we control for maternal mortality rates, allowing their impact to break in 1937 (i.e. we include post $t_{t}^{*}$ base_maternal mortalitys). This is crucial because maternal mortality declines may influence long-run outcomes for the cohorts in our sample. At the population level, parents may perceive greater returns to early life investments in girls when maternal mortality rates are lower, potentially leading to improvements in long-run outcomes for women vis-a-vis men (Jayachandran and Lleras-Muney, 2009). At the individual level, there are clearly consequences for boys and girls from one's own mother dying. There may be additional impacts flowing from changes in family size that arise because of changes in the probability of infertility, a potential complication of post-partum fever ${ }^{11}$.

Time-Varying State Characteristics: To further address pre-existing trends, we control for birth state-birth year varying socioeconomic variables including logged state income per capita, the numbers of schools, hospitals and physicians per capita, and state per capita public health spending ${ }^{12}$. The inclusion of income per capita in the state of birth is pertinent given changes in economic fortunes during the Depression Era, even if these have been shown to have had little, if any, impact on long-run health and economic outcomes (Cutler et al., 2007). To allow for any remaining converging/diverging trends at the birth state level, we investigate specifications with birth state specific linear (and quadratic) time trends and census division*birth year fixed effects. These additional specifications are motivated in part by convergence in economic development between the US South (which was particularly plagued by pneumonia) and other parts of the country during the $20^{\text {th }}$ century (Mitchener and MacLean, 1999).

Including these additional variables may amount to "over-controlling." For example, the increased risk of infections from weakened immune systems as well as competing risks from different conditions create population level correlations in disease rates. Thus, controlling for additional diseases may capture variation in disease trajectories that are in fact driven by the use of sulfa drugs rather than by unobserved confounding factors. Similarly,

\footnotetext{
11 Any such effects are necessarily indirect because the maternal post-partum infections (puerperal sepsis) that were controlled with sulfa drugs were not transmitted to infants.

12 The estimates are not sensitive to whether we include post multiplied by the pre-intervention level of the characteristic $\left(\right.$ post $\left._{t}^{*} X_{s}\right)$ or we directly include the characteristic $\left(X_{s t}\right)$.
} 
controlling for state trends is typically quite demanding of the data. We therefore present results with and without each set of controls. Robustness checks are, unless otherwise specified, presented for the specification with the richest set of controls. The robustness checks are detailed in the results section.

\subsection{Age of Exposure}

In an extension of the baseline specification which models birth year exposure, we allow for returns to sulfa exposure at other ages. Though far lower, pneumonia mortality rates were still considerable for those aged 1-5 (Figure 1). ${ }^{13}$ To investigate whether exposure to pneumonia at these ages had impacts, we replace post with a vector of birth year dummies for every year in the sample and then graph the coefficients on birth year*base_pneumonia. This specification also provides a useful falsification test: the presence of breaks in the coefficients in years other than around 1937 may suggest that the patterns seen in the data are due to some process other than the introduction of sulfa drugs. As we discuss later, we also exploit the age gradient in the coefficients to estimate a triple difference model, using the approximately ten-fold variation in pneumonia infection rates across age groups as an additional measure of treatment intensity.

\subsection{Gender and Race Heterogeneity}

Males may benefit more from early life medical interventions because they are biologically more vulnerable to infections, as well other aspects of an adverse early childhood health environment (Waldron, 1983; Low, 2000; Gluckman and Hanson, 2005). Indeed, surveillance data from the mid-1930s show that boys were $27 \%$ more likely to contract pneumonia in infancy than girls (Britten, 1942). Any biological differences may be moderated or reinforced by gender-specificity in the sensitivity of parental investments to health endowments. For example, human capital investments induced to complement the better health endowments of post-sulfa births may have been weaker for girls because of their more limited opportunities for advancement in the labor market (i.e., lower returns to investments). Evidence of a pro-male bias in contemporary times in the United States (Stanley and Jarell, 1998; Dahl and Moretti, 2008) lends credence to considering a behavioral angle in addition to biological factors.

${ }^{13}$ In contrast to Almond (2006) and Kelly (2009), we do not expect impacts from fetal exposure because mothers of childbearing age experienced very low infection rates (Britten, 1942). 
Race-specific models are warranted given that pre-sulfa pneumonia mortality for African Americans was about twice as high as that for whites, which implies that they had more to gain from the introduction of sulfa drugs. This alone would lead us to expect larger long-run impacts amongst blacks. On the other hand, there was racial segregation in hospital care and hospitals serving the black population were often less well equipped (Almond et al., 2006). Moreover, differentials in school quality and returns to education between blacks and whites were more marked prior to the Civil Rights Act of 1965 (Donohue and Heckman, 1991). Thus, human capital accumulation may not have responded to improved health endowments for blacks vis-à-vis whites for the reason discussed above in the case of women versus men - there may have been limited opportunities to capitalize on and lower returns to improved physical and mental endowments.

\section{Results}

\subsection{Main Results}

Refer Table 1, where each cell reports estimates of the coefficient on post $_{t}^{*}$ base_pneumonia $a_{s}$ from a separate regression. The rows denote the outcome variables and the columns different sets of control variables. We find that exposure to sulfa drugs, and thereby, reduced exposure to pneumonia has substantial and statistically significant impacts in the expected direction on every outcome for men. These results are remarkably robust to successive inclusion of controls for other diseases, state socioeconomic and infrastructure characteristics, state specific linear time trends, and census division X birth year fixed effects. The specification with all of these controls implies a post-sulfa gain of 0.19 in years of schooling associated with shifting the pre-sulfa pneumonia death rate (base_pneumonia) from the $75^{\text {th }}$ to the $25^{\text {th }}$ percentile of its distribution (i.e., from 1.18 to 0.92 deaths per 1,000). The same change in base implies a $2.83 \%$ increase in family income, a 0.42 percentage point decrease in the probability of being below $200 \%$ of the federal poverty line, a 0.75 percentage point increase in the probability of being employed, and a 0.61 percentage point decrease in the probability of reporting a disability limiting or preventing work. ${ }^{14}$

The estimated coefficients are of a similar magnitude for women in the specifications with birth state and birth year fixed effects and control diseases (columns 1 and 2). However,

\footnotetext{
14 A one standard deviation change in pre-intervention pneumonia is 0.19 . Our estimates suggests that this causes the following changes in long run outcomes: a 0.16 s.d. increase in education, a 0.04 increase in log income, a 0.02 percentage point increase in the chances of being employed and a 0.03 decrease in the risk of having a work-related disability.
} 
they are generally diminished and driven to insignificance by the inclusion of state socioeconomic variables and state specific trends. ${ }^{15}$ As we discuss below, invoking a third difference in age of exposure produces estimates for women that are robust to the richest set of controls.

Figures 5 and 6 plot the coefficients on birth year*base_pneumonia ${ }^{16}$ In line with the results in Table 1, the sharp sulfa trend breaks are either more muted or non-evident for the estimates for women. The coefficients for men show trend breaks consistent with the timing of the arrival of sulfa drugs. For almost all of the outcomes, the effect sizes jump and climb over the period 1937-1939, consistent with the earliest sulfa drugs being less effective in treating pneumonia than sulfapyridine, which was introduced in 1938 and became widely used by $1939 .{ }^{17}$ There is no evidence of trend breaks in years other than those associated with the introduction of sulfa. Furthermore, the coefficients for men prior to 1937 generally hover around zero indicating that the returns to sulfa exposure were likely limited to the birth year.

This suggests that the birth year is a "critical period" for investments designed to control infectious diseases and in particular pneumonia. As discussed earlier, this ties in with (a) pneumonia morbidity and mortality rates being far higher for infants than for older children and (b) the developmental changes induced by infectious disease being greater the younger the child is at exposure (Barker, 1992; Eppig et al., 2010).

\subsection{Additional Disability Variables}

A potential problem with our self-reported work related disability measure is that it may be prone to "justification bias" if the welfare regime encourages individuals to invent or exaggerate disability (Autor and Duggan, 2003). We investigate additional measures of disability that are unrelated to work participation and so may serve as cleaner measures of

\footnotetext{
15 We do not find any evidence of a relationship between exposure to lower maternal mortality rates and long-run outcomes. The coefficient on post*base_MMR tends to take the unexpected sign and is generally insignificant in Table 2 for men and women. So either reductions in maternal mortality did not change parental investments in a way that led to long-run changes in health and socioeconomic status, or the investment effects of maternal mortality declines through the pathways discussed earlier offset each other. The coefficients on the vector of sulfa-untreatable diseases similarly tend to be insignificant or of the unexpected sign.

16 These coefficients are from a specification with the controls in column 3 of Table 2. The plots look very similar if we include state specific trends in the control vector.

${ }_{17}$ We examined similar coefficient plots from an identical equation for heart disease, a control disease, trends in which were not directly influenced by the arrival of sulfa. We find no evidence of a trend break in 1937. These 'difference in difference' graphs are in Appendix Figures A2 and A3.
} 
health. These are indicators for whether individuals reported experiencing difficulties with basic physical and cognitive tasks, available only in the 2000 census when the marginal cohort is 63. There is some previous evidence that early life infections may accelerate cognitive decline in old age, possibly through their effects on cardiovascular health (Costa, 2005) or adult neurogenesis (Ekdahl et al., 2003)

The results are in Table 2. Men born after the introduction of sulfa drugs experienced a substantial reduction in the risk of cognitive disability. The estimates suggest that a move from the $75^{\text {th }}$ to $25^{\text {th }}$ percentile of the pre-sulfa baseline pneumonia mortality distribution is associated with a 0.66 percentage point decrease in the probability of reporting a cognitive disability amongst post-sulfa cohorts. The cognitive disability coefficients, while driven to insignificance upon inclusion of state specific trends, are not diminished in magnitude. The estimates for physical disabilities are sensitive to specification and not statistically significant. Women show no significant change in either disability risk post-sulfa.

The positive and significant findings for men across all outcomes versus the lack of such findings for women is consistent with men being biologically more vulnerable to early childhood health shocks than women. It is also consistent with reduced investment in women as a result of taste-based discrimination or statistical discrimination on the basis of low (expected) returns to human capital. We will return to this point below, and attempt to ascertain the relative importance of each explanation.

\subsection{Race Specific Effects}

Refer Tables 3-4. The results for white men and women mirror those for all men and all women, but the coefficients for African Americans are generally smaller and less imprecisely estimated. Poverty and cognitive disabilities are two important exceptions as black men show twice as large a sulfa-related reduction in both of these variables as white men, possibly because the treatment effect is larger in the region of the distribution where their baseline outcomes lie. Of note, while for both variables the estimates tend to lose significance as additional controls are added, they maintain their magnitudes and are consistently larger than the corresponding estimates for whites. To address whether the weaker estimates for blacks for the other outcomes are driven by measurement error in baseline mortality rates (which reflect changes for all races), we utilize race specific state 
mortality rates. ${ }^{18}$ While using the race-specific measure lowers the standard errors on the coefficients for blacks, there is still no evidence that their education, employment, income or work-related disability improved post-sulfa (results available upon request).

The race difference in our findings may arise for one of two reasons: (a) Either African Americans did not benefit as much from the arrival of sulfa in the 1930s or (b) they did but were unable to translate improved health and cognitive endowments into long run socioeconomic gains The first hypothesis is put forward in Jayachandran et al. (2010) who hypothesize that blacks had reduced access to hospitals and health care technology, thereby having reduced access to new therapeutics. However, the trends displayed in Figure 7 suggest a larger absolute decline in influenza and pneumonia mortality after 1937 for blacks than for whites. We confirm this in regressions which allow us to test for the statistical significance of this difference. We find that the trend break in pneumonia mortality and post-sulfa convergence across states are both significantly larger for blacks. ${ }^{19}$ It would seem that the reason this was feasible despite barriers to access to new treatments and segregation in hospital care is that sulfa drugs were initially available without prescription and widely used in the outpatient setting (section 2 above). Moreover, the cost of a course of treatment with this life-saving drug was relatively low, making it less likely that the relatively poor black population faced financial barriers to access (Lesch, 2007). ${ }^{20,21}$

\footnotetext{
18 The problem is that almost all states had much larger white than black populations, so the overall state mortality rate is a relatively noisy measure of black mortality. A solution is to use separate mortality rates for whites and non-whites within each state. However where the non-white population is very small, this will introduce measurement error again. To limit this problem, we followed Jayachandran, et al (2010) and used their data for states with greater than 10\% black populations; further limiting the sample to those states with non-white populations greater than 100,000 individuals.

${ }^{19}$ Using the sample window 1930-43, we regressed the pneumonia mortality rate (in levels, not logs) on post*year, controlling for the main effects of post and year and for state dummies. For this exercise we used the race-specific state-level mortality rates. The coefficient on post $t_{\text {year }}$ indicates a significant trend break in 1937 for both races, the coefficients being -0.14 (s.e. 0.016) for blacks and -0.08 (s.e. $0.010)$ for whites. To assess post-sulfa convergence in pneumonia across the states we regressed the pneumonia mortality rate on post $t^{*}$ base, defined as in equation (1). The coefficient on post*base is -0.56 (s.e. 0.111) for blacks and -0.27 (s.e. 0.185 ) for whites.

20 Jayachandran et al. (2010) analyze proportional changes in pneumonia mortality (relative to tuberculosis) for which there appears to be no significant race difference in the post-sulfa drop in mortality. This is clear in their Figure $6 \mathrm{~b}$ and we confirm with simple regressions of log mortality by race that the trend break in logs is similar.

${ }^{21}$ Our showing that pneumonia amongst African-Americans did respond to sulfa treatment not only puts aside hypothesis (a) concerning access to the drugs but also the idea that there are race
} 
We posit that our findings are more consistent with the second explanation. The larger impacts on cognitive disability and poverty suggest that blacks did benefit from the sulfa drug revolution in terms of formation of mental and physical endowments. However, the fact that these cohorts still derived no additional benefit in terms of schooling and employment later in adulthood is consistent with the fact that blacks had limited access to good schools, good jobs, and faced lower rates of return to human capital in the labor market in the pre-Civil Rights Era. Thus the discordance between the poverty and cognition outcomes and the other outcomes perhaps stems from the failure of investments in human capital to respond to improved endowments due to low rates of return.

The results for blacks perhaps inform the differential results by gender. However, if we pursue the interpretation of the cognitive disability and poverty impacts for blacks as implicit evidence of sulfa-drug induced improvements in endowments, the failure to find such effects for women, who may have faced similar institutional barriers to human capital investment, suggests that the biological sensitivity explanation may dominate the investment/institutions explanation for this population.

\subsection{Additional Robustness Checks}

Thus far, we have shown that our core findings are robust to the inclusion of a variety of birth state*birth year disease environment and macroeconomic controls, as well as flexible birth region trends and linear birth state-specific trends. We have also provided evidence in the form of flexible birth cohort specific coefficient plots that long run benefits of reduced pneumonia exposure led by the sulfa revolution are first visible for the cohort of 1937 and are increasing for cohorts born just after, consistent with the established timing of the introduction of sulfa drugs and the later development and adoption of sulfa varieties that were more potent in treating pneumonia. The evidence is also consistent with the epidemiology of pneumonia, which targets infants far more ruthlessly than somewhat older children.

In this section, we consider a number of additional robustness/falsification checks. Two relate to the flexible coefficient plots in Figures 5 and 6. In the first, we re-estimate the model with a placebo intervention, defining post as 1934 rather than as 1937 onwards. We now find no evidence of any long run gains (Table A2). In the second, we further formalize

differences in the way that disease takes hold and, consequently, the way that it responds to treatments. 
the intuition behind the coefficient plots. As discussed, infection rates and days of disability suffered by pneumonia patients in the pre-sulfa era (1934-36) peaked at birth and reached a minimum in the age group 10-24. The difference was a factor of eight to ten (Collins 1931, Britten 1942; Figure 1 below). Consequently we expect limited if any long run benefits of sulfa to be evident for individuals who were first exposed at, say, age 15 compared with individuals exposed at birth.

We use this insight to estimate a triple difference specification. For this we extended the sample back to birth cohorts 1915 and onwards. We now define treated as 1 for individuals who were exposed to sulfa at birth (ie born in or after 1937) and as 0 for individual who had their first exposure to sulfa at age 10-15. Post is now equal to 1 for treated individuals born on or after 1937 and untreated individuals who turned 15 on or after 1937. Appendix Figure 1 provides a visual description of how the treatment and control groups are set up. The regressor of interest is now post*treated*base_pneumonia and we naturally include the underlying two-way interactions and main effects.

The results are in Table 5, using the richest set of controls, corresponding to column 5 in Table 1. For men, the estimates are remarkably similar in magnitude and significance to those in Table $1 .^{22}$ Interestingly, the results for women now show large positive estimates for schooling, family income and employment, all of which are statistically significant. Sulfainduced gains in schooling and income are smaller for women than for men but their employment gains are twice as large. ${ }^{23}$ We also now find a significant improvement in work disability for black men, which ties in with our finding of improvements for this group in other indicators of disability.

An additional source of bias may come from selective migration. Since the US census records the state of birth, we are confident that we are correctly matching individual (or

\footnotetext{
${ }^{22}$ This not only once again reinforces the robustness of the estimates for men but it also tells us that the triple difference model works sensibly.

23 Why are the estimates for women more robust to controls for trended unobservables with a triple difference than they were with the double difference? It may be that for women we need a longer difference to detect impacts. This is what treated at age 0 versus at age 10-15 adds. This may be either because the sulfa effects for women are smaller and so just harder to detect, or because outcomes for women had a stronger underlying trend and this makes it harder to detect a discontinuity using immediately neighboring cohorts. Overall, the evidence for women is somewhat ambiguous but what is clear from studying the double and triple difference estimates is that the coefficients for women are (a) smaller for schooling, income and disability and (b) less robust to controls.
} 
cohort) outcomes to pneumonia mortality rates faced during infancy ${ }^{24}$. However, we cannot be sure that the state of birth is truly exogenous. That is, parents may have migrated in response to sulfa, thereby selecting the birth state of their children. ${ }^{25}$ This will introduce endogeneity of the base_pneumonia variable in our regressions, to the extent that migrants are selected on unobservable parental attributes. We therefore test for this possibility using information on 20-40 year olds in the 1930 and 1940 census files. ${ }^{26}$ We regressed log population on post*base_pneumonia, and state and year fixed effects (Table A3). This shows the expected positive effect of sulfa drugs on population - that is, people of child-bearing age who were likely to become parents preferentially moved to states that saw larger reductions in pneumonia and other sulfa treatable diseases. However, this effect is completely dissipated upon controlling for baseline diarrheal mortality and/or state income per capita (which our main models control for), suggesting that disease environment driven migration is not driving our main results.

We also test the sensitivity of our core findings to meaningful changes in the estimation sample. First, as in Jayachandran et al. (2010) we re-estimate the equations removing the 1935 and 1936 birth cohorts as there was a minor influenza epidemic during these years. The point estimates are larger and the qualitative conclusions remain similar (Table A4). We experimented with narrowing the window length and, in particular, dropping cohorts born after 1941, which is when the US joined the Second World War. The standard errors rise but the coefficients are in general fairly robust (results available upon request). To check whether the results are driven by the convergence between the South and the rest of the country for reasons other than the arrival of sulfa drugs, we re-estimated the equations

\footnotetext{
${ }^{24}$ Regardless, we estimated models that control for the current state of residence in addition to the birth state (as in Case and Paxson 2009), and where we only focus on those who moved to states other than their birth state. In neither case were there substantive changes to our results (available on request). These checks indicate that the impacts we identify are not driven by post-birth migration in the direction of better opportunities.

${ }^{25}$ Montalvo and Reynal-Querol (2007) analyse the reverse process i.e. how levels of infectious disease respond to migration patterns. The possibility that migration may respond to the infectious disease environment has been discussed by Mesnard and Seabright (2009) but we are not aware of many tests of this. We are grateful to Alice Mesnard for alerting us to this.

26 We constructed a state level data set with the number of 20-40 year olds in each state in the years 1930, 1935 and 1940 (the 1940 census asks individuals to report their state of residence five years before enumeration, hence the 1935 data point). Selecting age 20-40 is appropriate because we are interested in endogeneity of the birth state of our cohorts born in the 1930s. As birth and death create changes in population that are concentrated at the two ends of the age distribution, looking at changes in the population aged $20-40$ is likely to isolate migration.
} 
excluding the South. While the coefficients on schooling and work disability (human capital) are smaller, the coefficients for income, poverty and employment (returns to human capital) are very similar although less precisely determined (Table A5). We also conducted specification checks relating to our use of the census data (results available upon request). There is some concern in the literature that the 2000 census microdata sample used in this paper may be subject to inaccuracies in age reporting (Alexander et al., 2010). While this problem primarily pertains to those over the age of 65 , all of whom were born at least two years prior to the start of the sulfa era, we still assessed whether our results remained the same if the 2000 census was excluded. The substantive results are unchanged. All in all, the rich set of controls and the array of robustness checks allay the concern that our estimates are driven by unobserved convergence processes, reinforcing our attribution of the estimates to causal effects of pneumonia exposure.

\subsection{Participation, Selection, and Size of Effects}

Our estimates are likely to under-state the impact of birth year exposure to sulfa drug driven reductions in pneumonia morbidity and mortality for the following reasons. First, the estimates describe cohort averages. However, not everyone was afflicted by pneumonia and, among those who were, not everyone was treated by sulfa drugs. Thus, to at least approximate intent-to-treat estimates among those who had the disease, we would have to divide our estimates by the fraction of infants with pneumonia. As discussed in section 2, there are no consistent data on historical infection rates. If we take a case rate of 15 per 100 child-years to approximate the situation in today's developing countries, our results for males indicate that, moving from a state at the $75^{\text {th }}$ percentile of the pre-intervention pneumonia mortality rate to a state at the $25^{\text {th }}$ percentile was associated with the following post-sulfa improvements for individuals who actually had pneumonia (refer column 5 of Table 1): an increase in schooling of 1.27 years, a $18.87 \%$ increase in family income, a $2.8 \%$ point decline in the probability that family income falls below $200 \%$ of the poverty line, a $5 \%$ point increase in the probability of employment, and a $4.07 \%$ point decrease in the probability of reporting a work preventing disability. These calculations ignore within-cohort spillover effects from those afflicted by pneumonia to those that were not. The estimates are large but plausible since pneumonia was a long, trying illness. Pneumonia led to an average of 39 days of disability per patient in the year just before sulfa arrived (Britten, 1942). Also these 
estimates are in the same ballpark as recent estimates of the long-run impact of malaria eradication or de-worming in developing countries. ${ }^{27}$

Furthermore, conditional upon infection, access to and use of sulfa drugs to treat pneumonia may not have been universal, at least in the early years.. This suggests that our estimate likely lies below the true average treatment effect on the treated, which is difficult to calculate given that there are no available data on the fraction of individuals plagued by pneumonia who received sulfa therapy.

Finally, mortality selection will tend to bias our estimates downwards since frail children were probably more likely to succumb to pneumonia than their healthier counterparts (Bozzoli et al., 2009). With the advent of sulfa drugs, more of these children would survive past childhood and these innately less healthy individuals are likely to be less productive and healthy as adults. Mortality also has another sort of implication that typically goes unrecognized. Consider a child, $j$, born in or after 1937 who is a marginal survivor on account of sulfa drugs. For a given health endowment, parents may lower their health investment in the next child in that family, $j+1$, (born, let us say, in 1939). In other words, we will under-estimate sulfa-induced gains to the extent that post-sulfa cohorts have more surviving siblings and there is resource competition between siblings. We expect any mortality-related bias to be small since pre-intervention death rates amongst infants were around 1\% (Britten, 1942; Councell, 1963).

\section{Conclusions}

This study delivers the first estimates of the long-run returns to investment in medical innovation (of antibiotics) and the first causal evidence of long-term scarring effects of early life exposure to pneumonia on indicators of later life health and socioeconomic status. Our results suggest that exogenously delivered early life health improvements created some tendency towards convergence in socioeconomic status across states and within the most effectively treated group (white men) forty to sixty years later. However they generated

\footnotetext{
${ }^{27}$ Malaria eradication is estimated to have led to a $15-27 \%$ increase in wage income (Bleakley, 2010) and about a 3 year increase in schooling (Lucas, 2010). De-worming in primary schools is estimated to have generated 2-3 additional years of schooling and a 21-29\% increase in income (Baird et al., 2011). The four-fold increase in infection (via mothers) during the 1918 influenza epidemic led to 0.25 years less education and 6\% lower income (Almond, 2006). We present estimates of the change in long run outcomes for post-sulfa cohorts by simulating the effects of a change in pre-intervention pneumonia from the $75^{\text {th }}$ to the $25^{\text {th }}$ percentile of its distribution (which is a $0.26 \%$ point change). The actual pre-post 1937 drop in pneumonia was, as it happens, similar, at 30\%: pneumonia mortality fell from 1.1 to 0.79 per 1000 between 1936 and 1938 .
} 
a more limited narrowing of socioeconomic inequalities across gender and race groups. Women exhibit socioeconomic gains in a number of specifications but their education and income gains are smaller, consistent with girls being less likely to contract infections in infancy and more robust to fighting them off if they do. In contrast, African-Americans were more likely to contract infections including pneumonia and they gained more from the arrival of the new antibacterials. However they appear to have faced institutional constraints in translating improved early life health endowments into educational capital and employment.

Our results are important for developing countries where acute respiratory infections are the leading cause of early childhood mortality. The evidence base from developing countries on medical interventions targeting pneumonia in children is beginning to grow. For example, a recent community-based intervention in India that involved treatment of pneumonia in children aged 0-4 years with co-trimoxazole showed a case-fatality rate of $0.8 \%$ in the treatment area compared with $13.5 \%$ in the control area. The cost of cotrimoxazole was US $\$ 0.025$ per child per year or $\$ 2.64$ per child saved (Bang et al., 1999). In addition, large scale roll-outs of pneumococcal vaccines have shown to be highly efficacious in reducing pneumonia incidence and mortality in developed and developing countries alike (Cutts et al., 2005).

Although we now have the technology to prevent and treat pneumonia, only $20 \%$ of children with pneumonia in developing countries receive the necessary antibiotics (WHO 2010). ${ }^{28}$ The Advance Market Commitment (AMC) and the Health Impact Fund (HIF) are recent initiatives directed at garnering commitment of international resources to finance preventative and therapeutic innovations and also their large scale distribution in poor countries. ${ }^{29}$ The first AMC pilot, agreed in 2007, is the pneumococcal vaccine. This is now affordable for children in a number of developing countries and it is estimated that it can

\footnotetext{
28 As priced, antibiotics are largely unaffordable to the poor in developing countries. In part this probably reflects institutional failures that mark the provision of health-related and other public services. In addition there appears to be a perception that antibiotics are inappropriately used in developing countries, and this contributes to vaccines being seen as a more promising alternative.

${ }^{29}$ Collective action to combat infectious diseases is merited by the presence of infection externalities. In addition to the ethical case for global action (Pogge 2004, 2009) is the public goods nature of $\mathrm{R} \& \mathrm{D}$ advances related to treating infectious disease.
} 
prevent more than seven million childhood deaths by $2030 .{ }^{30}$ The sustainability of these initiatives and in particular the HIF depends upon measurement of health impact (Grootendorst, 2009). Our work makes a unique contribution in this context. The standard approach is to look for immediate reductions in morbidity and mortality at the patient level, often summarized in quality or disability adjusted life years. We show that the benefits of treating pneumonia in childhood are, for a given cost, much larger than the standard approach would suggest. This is because the standard approach ignores (a) long run and (b) socio-economic benefits for survivors and (c) the externalities that flow from lowering the duration and intensity of illness. Accounting for dynamic gains in the health and socioeconomic domain at the population level (so accounting for externalities) helps construct an efficiency case for investment that enhances extant ethical and equity-driven considerations motivating new global health interventions that target young children. ${ }^{31}$

Our analysis of gender and race differentials in treatment effects suggests that the translation of childhood health gains into later life education and productivity may be a function of social and political constraints embodied in local or national institutions. This provides a compelling illustration of the interaction of childhood health endowments with environmentally determined incentives for parents to invest in human capital. Further work is merited in two directions. First, in enriching the set of outcomes examined, to include cognitive test scores and further indicators of health status. Second, to provide clearer insight into the manner in which biological pathways interact with parental investments and socio-political institutions.

\section{References}

D. Acemoglu and S. Johnson (2007), 'Disease and Development: The Effect of Life Expectancy on Economic Growth', Journal of Political Economy 115(6): 925-965.

J. T. Alexander, M. Davern and B. Stevenson (2010), 'Inaccurate Age and Sex Data in the Census PUMS Files: Evidence and Implications', NBER Working Paper 15703.

\footnotetext{
${ }^{30} \mathrm{http} / /$ www.gavialliance.org/funding/pneumococcal-amc/, http://www.yale.edu/macmillan/igh/. In February 2007, five countries together with the Gates Foundation committed \$1.5billion to launch the pneumococcal pilot. As of August 2011, 19 GAVI-eligible countries have been approved to receive pneumococcal vaccine support and GAVI plans to support the rollout of pneumococcal vaccines in more than 40 countries by 2015. GAVI is the Global Alliance for Vaccination and Immunization.

${ }^{31}$ Longitudinal data are increasingly being collected in poor countries (Glewwe and Miguel, 2008) but even in cases where only short run impacts are observable, our estimates suggest an order of magnitude for how short run impacts may be scaled up to allow for long run impacts.
} 
D. Almond (2006), 'Is the 1918 Influenza Pandemic Over? Long-Term Effects of In Utero Influenza Exposure in the Post-1940 U.S. Population', Journal of Political Economy 114(4): 671-712.

D. Almond, K. Chay and M. Greenstone (2006), 'Civil Rights, the War on Poverty, and Black-White Convergence in Infant Mortality in the Rural South and Mississippi', MIT Department of Economics.

D. Almond and J. Currie (2011), 'Human Capital Development Before Age Five ', in Ashenfelter, O. and Card, D., eds., Handbook of Labor Economics, Vol 4b: Elsevier.

D. Almond and B. Mazumder (2011), 'Health Capital and the Prenatal Environment: The Effect of Ramadan Observance During Pregnancy', Forthcoming, American Economic Journal: Applied Economics.

D. H. Autor and M. G. Duggan (2003), 'The Rise in Disability Rolls and the Decline in Unemployment', Quarterly Journal of Economics 118(1): 157-205.

S. Baird, J. H. Hicks, M. Kremer and E. Miguel (2011), 'Worms and Work: Long-Run Impacts of Child Health Gains', mimeo, University of California, Berkeley.

A. Banerjee, E. Duflo, G. Postel-Vinay and T. Watts (2010), 'Long-Run Health Impacts of Income Shocks: Wine and Phylloxera in Nineteenth-Century France', The Review of Economics and Statistics 92(4): 714-728.

A. T. Bang, R. A. Bang, S. B. Baitule, M. H. Reddy and M. D. Desmukh (1999), 'Effect of Home-Based Neonatal Care and Management of Sepsis on Neonatal Mortality: Field Trial in Rural India', The Lancet 354: 1955-1961.

D. Barker (1992), Fetal and Infant Origins of Adult Disease, London: British Medical Journal Publishing Group.

A. Barreca (2010), 'The Long-Term Economic Impact of In Utero and Postnatal Exposure to Malaria', Journal of Human Resources 45(4): 865-892.

A. Barreca, P. Fishback and S. Kantor (2011), 'The Impact of Migration on Malaria Deaths in the Early 20th Century United States', mimeo, Tulane University.

M. Bertrand, E. Duflo and S. Mullainathan (2004), 'How much should we trust differencesin-differences estimates?', Quarterly Journal of Economics 119(1): 249-275.

Z. A. Bhutta (2007), 'Dealing with Childhood Pneumonia in Developing Countries: How Can We Make a Difference', Archives of Disease in Childhood 92: 286-288.

R. E. Black, S. Cousens, H. L. Johnson, J. E. Lawn, I. Rudan, D. G. Bassani, P. Jha, H. Campbell, C. Fischer Walker, R. Cibulskis, T. Eisele, L. Liu and C. Mathers (2010), 'Global, Regional, and National Causes of Child Mortality in 2008: A Systematic Analysis', The Lancet 375: 1969-1987.

S. E. Black, P. J. Devereux and K. G. Salvanes (2007), 'From the Cradle to the Labor Market? The Effect of Birth Weight on Adult Outcomes', Quarterly Journal of Economics 122(1): 409-439.

H. Bleakley (2007), 'Disease and Development: Evidence from Hookworm Eradication in the American South', The Quarterly Journal of Economics 122(1): 73-117.

H. Bleakley (2010), 'Malaria Eradication in the Americas: A Retrospective Analysis of Childhood Exposure', American Economic Journal: Applied Economics 2: 1-45.

C. Bozzoli, A. Deaton and C. Quintana-Domeque (2009), 'Adult Height and Childhood Disease', Demography 46(4): 647-669.

R. H. Britten (1942), 'The Incidence of Pneumonia as Recorded in the National Health Survey', Public Health Reports 57(40): 1479-1494. 
A. Case and C. Paxson (2010), 'Early Life Health and Cognitive Function in Old Age', American Economic Review: Papers and Proceedings 99(2): 104-109.

K. Y. Chay, J. Guryan and B. Mazumder (2009), 'Birth Cohort and the Black-White Achievement Gap: The Roles of Access and Health Soon After Birth', Federal Reserve Bank of Chicago Working Paper.

M. L. Cohen (2000), 'Changing Patterns of Infectious Disease', Nature 406: 762-767.

D. Costa (2005), 'Causes of Improving Health and Longevity at Order Ages: A Review of the Explanation', Genus 71(1): 21-38.

C. E. Councell (1963), 'Recent Trends for Pneumonia Mortality', Public Health Reports 78(2): 178-182.

E. M. Crimmins and C. E. Finch (2004), 'Inflammatory Exposure and Historical in Human Life-Spans', Science 305(5691): 1736-1739

E. M. Crimmins and C. E. Finch (2006a), 'Commentary: Do older men and women gain equally from improving childhood conditions?', International Journal of Epidemiology 35(5): 1264-1269.

E. M. Crimmins and C. E. Finch (2006b), 'Infection, Inflammation, Height, and Longevity', Proceedings of the National Academy of Sciences 103(2): 498-503.

F. Cunha and J. Heckman (2007), 'The technology of skill formation', American Economic Review 97(2): 31-47.

F. Cunha and J. J. Heckman (2009), 'The Economics and Psychology of Inequality and Human Development', Journal of the European Economic Association 7(2): 320364.

J. Currie (2009), 'Healthy, Wealthy, and Wise: Socioeconomic Status, Poor Health in Childhood, and Human Capital Development ', Journal of Economic Literature 47(1): 87-122.

D. Cutler, W. Fung, M. Kremer, M. Singhal and T. Vogl (2010), 'Early-Life Malaria Exposure and Adult Outcomes: Evidence from Malaria Eradication in India', American Economic Journal: Applied Economics 2: 72-94.

D. M. Cutler, G. Miller and D. M. Norton (2007), 'Evidence on Early-Life Income and LateLife Health from America's Dust Bowl Era', Proceedings of the National Academy of Sciences 104(33): 13244-13249.

F. T. Cutts, S. M. A. Zaman, G. Enwere, S. Jaffar, O. S. Levine, J. B. Okoko, C. Oluwalana, A. Vaughan, S. K. Obaro, A. Leach, K. P. McAdam, E. Biney, M. Saaka, U. Onwuchekwa, F. Yallop, N. F. Pierce, B. M. Greenwood and R. A. Adegbola (2005), 'Efficacy of Nine-Valent Pneumococcal Conjugate Vaccine Against Pneumonia and Invasive Pneumococcal Disease in The Gambia: Randomized, Double-Blind, Placebo-Controlled Trial', The Lancet 365: 1139-1146.

G. B. Dahl and E. Moretti (2008), 'The Demand for Sons', Review of Economic Studies 75: 1085-1120.

J. J. Donohue and J. J. Heckman (1991), 'Continuous Versus Episodic Change: The Impact of Civil Rights Policy on the Economic Status of Blacks', Journal of Economic Literature 29(4): 1603-1643.

C. Ekdahl, J. Claasan, S. Bonde, Z. Kokaia and O. Lindvall (2003), 'Inflammation is Detrimental for Neurogenesis in Adult Brain', Proceedings of the National Academy of Science 100: 13632-13637.

C. Eppig, C. L. Fincher and R. Thornhill (2010), 'Parasite Prevalence and the Worldwide Distribution of Cognitive Ability', Proceedings of the Royal Society B 277(1701): 3801-3808. 
G. M. Evans and W. F. Gaisford (1938), 'Treatment of Pneumonia with 2-(paminobenzenesulphonamido) Pyridine', The Lancet Infectious Diseases 232(5992): 14-19.

M. Finland (1960), 'Treatment of Pneumonia and Other Serious Infections', The New England Journal of Medicine 263(5): 207-221.

W. F. Gaisford (1939), 'Results of the Treatment of 400 Cases of Lobar Pneumonia with M\&B 693', Proceedings of the Royal Society of Medicine 32(9): 1070-1076.

J. L. Gallup and J. D. Sachs (2001), 'The Economic Burden of Malaria', American Journal of Tropical Medicine and Hygiene 64((1,2)S): 85-96.

G. F. Gibberd (1937), 'Prontosil and Similar Compounds in the Treatment of Puerperal Haemolytic Streptococcus Infections', British Medical Journal 2: 695-698.

P. Glewwe and E. Miguel (2008), 'The Impact of Child Health and Nutrition on Education in Less Developed Countries', in Strauss, J. and Schultz, T., eds., Handbook of Development Economics: Elsevier.

S. Glied and A. Lleras-Muney (2008), 'Technology Innovation and Inequality in Health', Demography 45(3): 741-761.

P. D. Gluckman and M. A. Hanson (2005), The fetal matrix: evolution, development, and disease, Cambridge, UK ; New York: Cambridge University Press.

J. Greengard, W. B. Raycraft and W. G. Motel (1943), 'Effects of Chemotherapy on Pneumonia in Infants Under One Year of Age', American Journal of Diseases of Children 62(730-742).

P. Grootendorst (2009), 'How Should We Support Pharmaceutical Innovation?', Expert Rev. Pharmacoeconomics Outcomes Res. 9(4): 313-320.

H. L. Hodes, W. C. Stifler, E. Walker, M. McCarty and R. G. Shirley (1939), 'The Use of Sulfapyridine in Primary Pneumococcic Pneumonia and in Pneumoccic Pneumonia Associated With Measles', The Journal of Pediatrics 14(4): 417-446.

S. Jayachandran and A. Lleras-Muney (2009), 'Life Expectancy and Human Capital Investments: Evidence from Maternal Mortality Declines', The Quarterly Journal of Economics 124(1): 349-397.

S. Jayachandran, A. Lleras-Muney and K. V. Smith (2010), 'Modern Medicine and the 20thCentury Decline in Mortality: Evidence on the Impact of Sulfa Drugs', American Economic Journal: Applied Economics 2(2): 118-146.

E. Kelly (2009), 'The Source of Asian Flu: in utero Exposure to Pandemic Influenza and the Development of a Cohort of British Children', Institute for Fiscal Studies Working Paper W09/17.

D. M. Kiefer (2001), 'Miracle Medicines: The Advent of the Sulfa Drugs in the Mid-1930s Gave Physicians a Powerful Weapon', Today's Chemist at Work 10 (6): 59-60.

K. P. Klugman and C. Feldman (2009), 'Pneumococcal Infections', in Evans, A. S. and Brachman, P. S., eds., Bacterial Infections of Humans: Epidemiology and Control, New York: Springer.

J. E. Lesch (2007), The First Miracle Drugs: How the Sulfa Drugs Transformed Medicine, New York, NY: Oxford University Press.

F. E. Linder and R. D. Grove (1947), Vital Statistics in the United States 1900-1940, Washington, DC: United States Government Printing Office.

P. H. Long and E. A. Bliss (1937), 'Observations Upon the Experimental and Clinical Use of Sulphanilamode in the Treatment of Certain Infections', Journal of the American Medical Association 108: 32-37. 
A. D. Lopez, C. D. Mathers, M. Ezzati, D. T. Jamison and C. J. Murray (2006), Global Burden of Disease, Washington (DC): World Bank.

B. S. Low (2000), Why sex matters : a Darwinian look at human behavior, Princeton, NJ: Princeton University Press.

A. Lucas (2010), 'Malaria Eradication and Educational Attainment: Evidence from Paraguay and Sri Lanka', American Economic Journal: Applied Economics 2: 46-71.

J. E. McGowan, M. W. Barnes and M. Finland (1975), 'Bacteremia at Boston City Hospital: Occurence and Mortality During 12 Selected Years (1935-1972), with Special Reference to Hospital-Acquired Cases', Journal of Infectious Diseases 132(3): 316335.

K. J. Mitchener and I. W. MacLean (1999), 'U.S. Regional Growth and Convergence, 18801980', Journal of Economic History 59(4): 1016-1042.

J. Montalvo and M. Reynal-Querol (2007), 'Fighting against malaria: prevent wars while waiting for the miraculous vaccines', The Review of Economics and Statistics 89(1): 165-177.

E. E. Moody and E. G. Knouf (1940), 'Pneumonia in Children: Treatment with Sulfapyridine', California and Western Medicine 53(3): 116-123.

I. Rudan, L. Tomaskovic, C. Boschi-Pinto and H. Campbell (2004), 'Global Estimate of the Incidence of Clinical Pneumonia Among Children Under Five Years of Age', Bulletin of the World Health Organization 82 (12): 895-903.

S. Ruggles, J. T. Alexander, K. Genadek, R. Goeken, M. B. Schroeder and M. Sobek (2010), 'Intergrated Public Use Microdata Series: Version 5.0 [Machine-readable Database]', in, Minneapolis: University of Minnesota.

S. Shaheen (1997), 'The Beginnings of Chronic Airflow Obstruction', British Medical Bulletin 53: 58-70.

C. H. Smith and R. L. Nemir (1939), 'The Sulfapyridine Treatment of Pneumonia in Children', Journal of the American Medical Association 113(21): 1857-1860.

T. D. Stanley and S. B. Jarell (1998), 'Gender Wage Discrimination Bias? A Meta-Regression Analysis', The Journal of Human Resources 33(4): 947-973.

A. D. Stein, H. X. Barnhart, M. Hickey, U. Ramakrishnan, D. G. Schroeder and R. Martorell (2003), 'Prospective study of protein-energy supplementation early in life and of growth in the subsequent generation in Guatemala', Am J Clin Nutr 78(1): 162-167.

M. A. Thomasson and J. Treber (2008), 'From Home to Hospital: The Evolution of Childbirth in the United States, 1928-1940', Explorations in Economic History 45(1): 76-99.

H. E. Ungerleider, H. W. Steinhaus and R. S. Gubner (1943), 'Public Health and Economic Aspects of Pneumonia - A Comparison with Pre-Sulfonomide Years', American Journal of Public Health 33: 1093-1102.

G. L. van der Berg, M. Lindebloom and F. Portrait (2007), 'Long-Run Longevity Effects of a Nutritional Shock Early in Life', IZA Discussion Paper No. 3123.

T. van der Poll and S. M. Opal (2009), 'Pathogenesis, Treatment, and Prevention of Pneumococcal Pneumonia', The Lancet 374: 1543-1556.

A. Venkataramani (2010), 'Early Life Exposure to Malaria and Cognition in Adulthood: Evidence from Mexico', Mimeo, Washington University School of Medicine.

I. Waldron (1983), 'The Role of Genetic and Biological Factors in Sex Differences in Mortality', in Lopez, A. D. and Ruzicka, L. T., eds., Sex Differentials in Mortality: Trends, Determinants and Consequences, Canberra and New York, NY: Dept. of Demography, PB Consulting Service. 
M. E. Wegman (2001), 'Infant Mortality in the 20th Century, Dramatic but Uneven Progress', Journal of Nutrition 131(Suppl): 401S-408S.

World Health Organization (2010), 'Pneumonia, Factsheet No. 331', in. 


\section{Figures}

Figure 1: The Age Distribution of Pneumonia in the 1930s

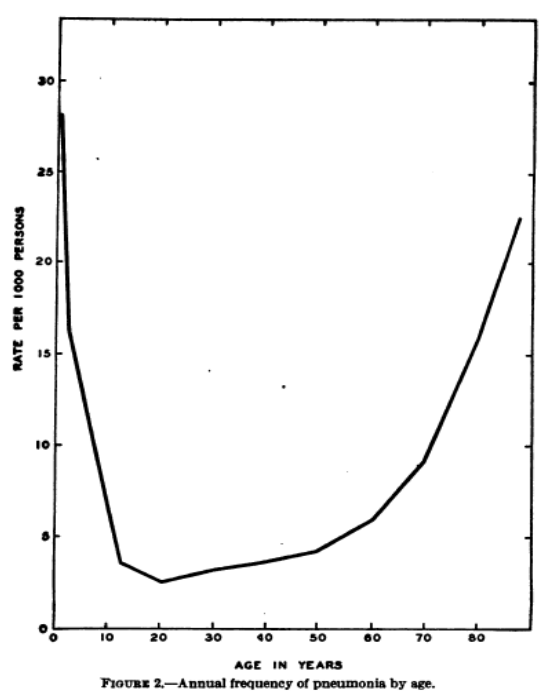

Source: Britten (1942).

Figure 2 - Geographic Distribution of Pneumonia Mortality Rates, 1930-1936

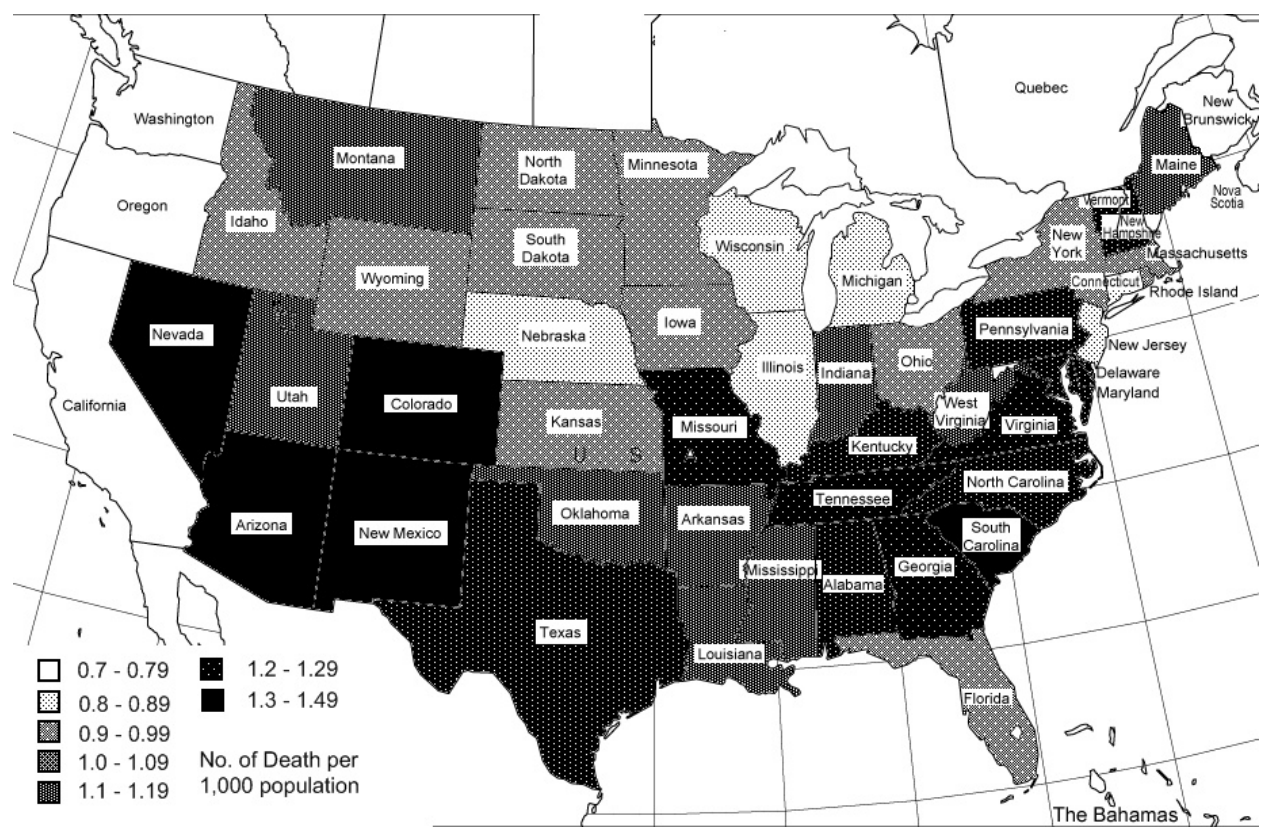

Source: Map drawn by the authors using the all-age influenza and pneumonia mortality rate from the US Vital Statistics. 
Figure 3 - Trend Break in Pneumonia Mortality Coincident with Arrival of Sulfa

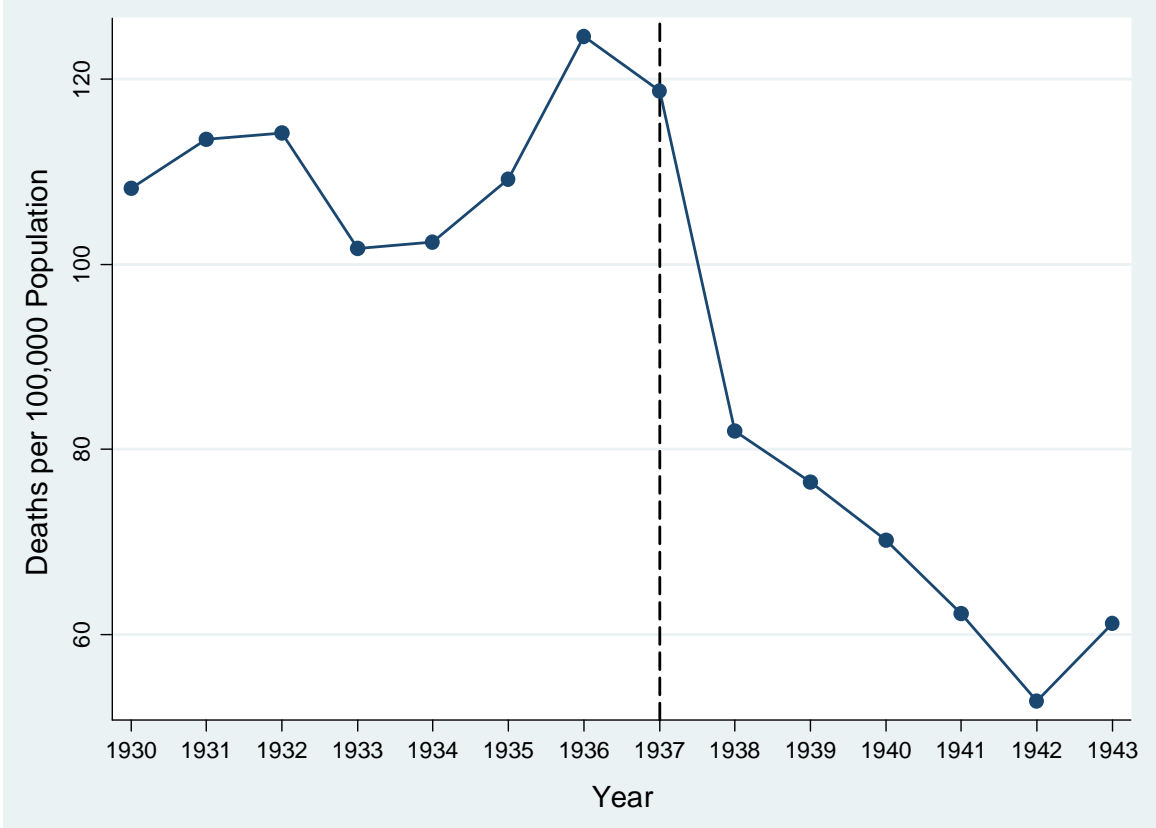

Source: US Vital Statistics

Figure 4 - Post-Sulfa Reduction in Pneumonia Mortality Rates by Baseline Rates

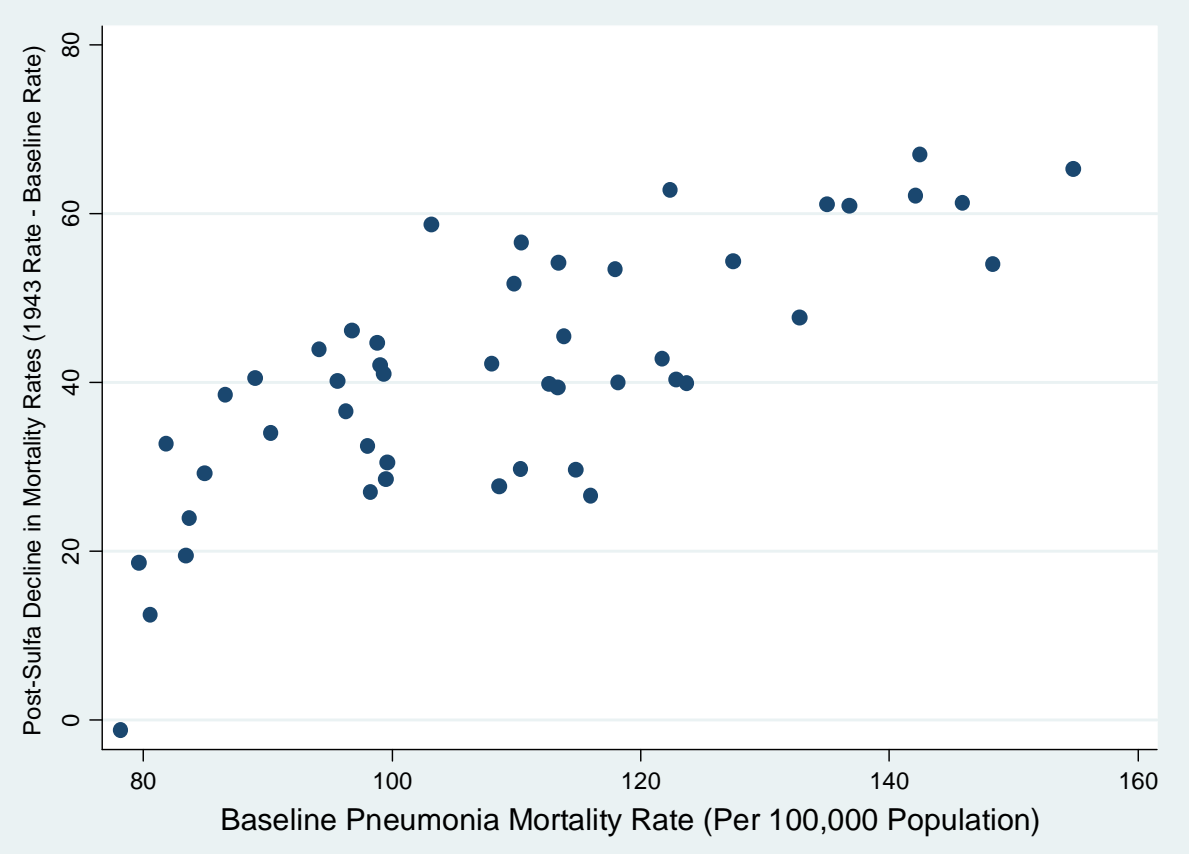

Source: US Vital Statistics 
Figure 5a. All Men: Birth-Year Specific Coefficients on Pre-Intervention Pneumonia Mortality Rates

Work Limiting Disability

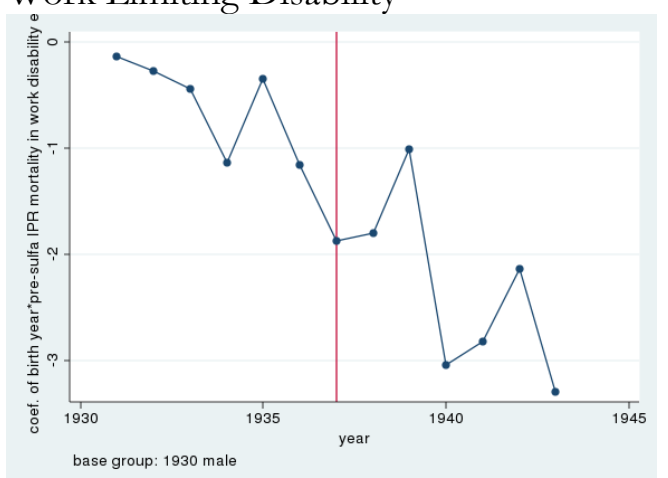

Family Income

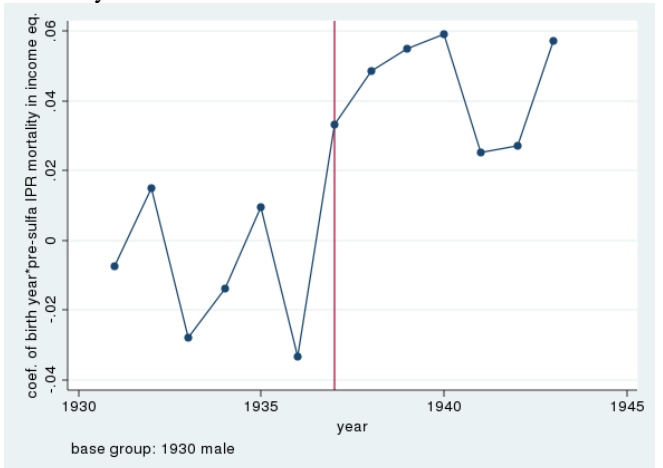

Employment

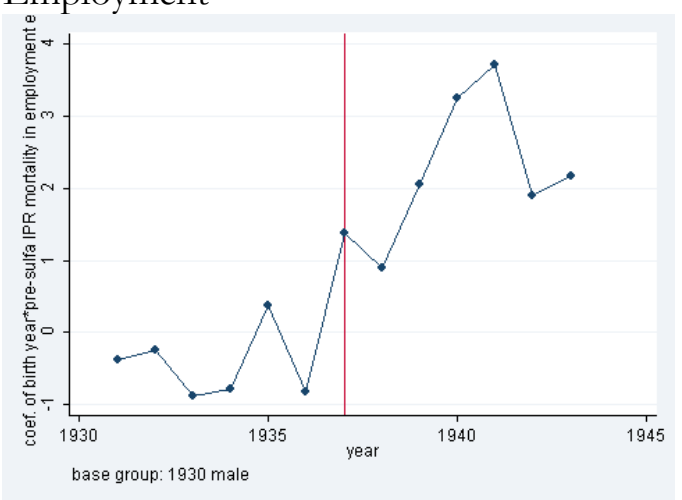

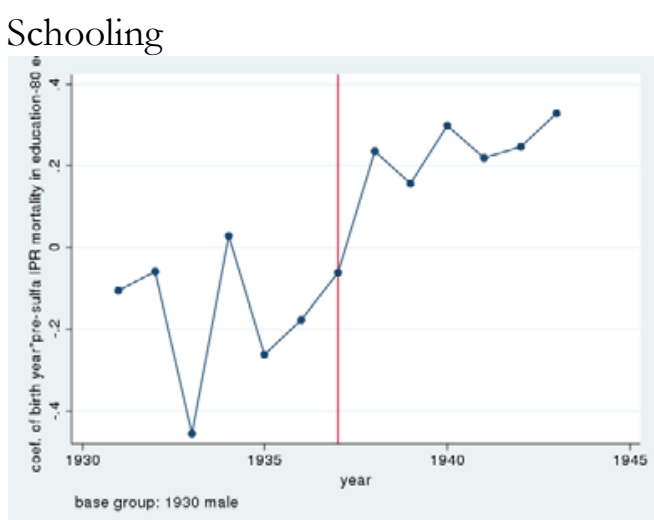

Poverty

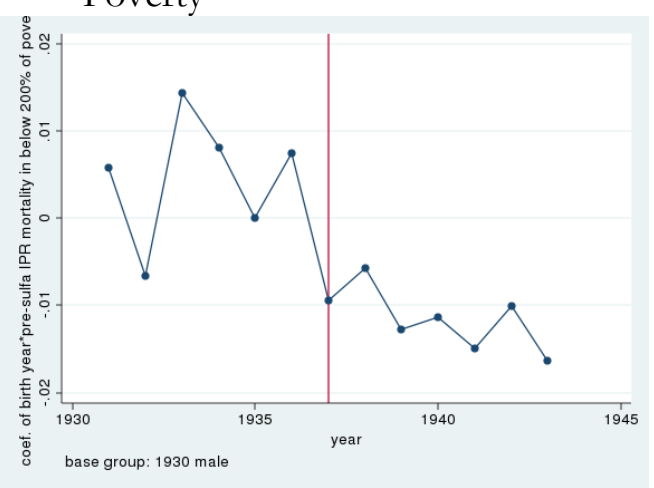

Notes: Each point reflects the estimate on the interaction between the marked birth year and the pre-intervention (base) level of the pneumonia mortality rate in the birth-state. This is conditional upon birth state and birth year fixed effects and the full set of controls for mortality from other diseases and state macroeconomic and infrastructure variables (i.e., the control vector in Column 3 of Table 1). The vertical line denotes the year sulfa drugs became available in the United States. Agents more efficacious against pneumonia became available in 1938. Plots including a control disease are in Appendix Figures A2, A3. These plots show how the sharp fall in pneumonia in 1937 seen in Figure 3 is mirrored in socioeconomic and health indicators in 1980-2000. 
Figure 5b. All Women: Birth-Year Specific Coefficients on Pre-Intervention Pneumonia Mortality Rates

Work Limiting disability

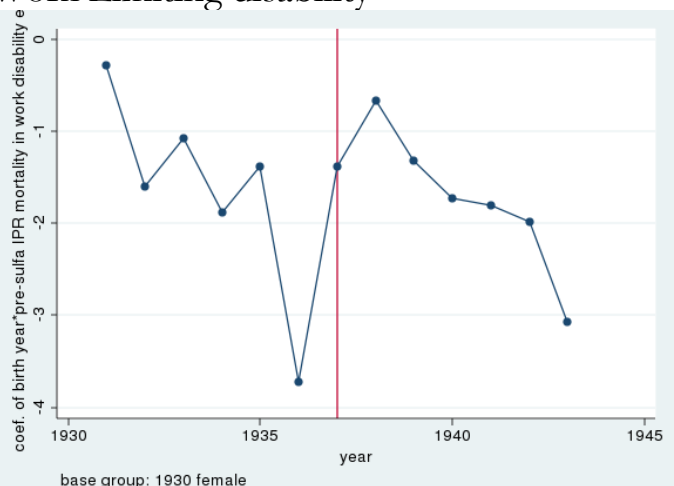

base group: 1930 female

Family Income

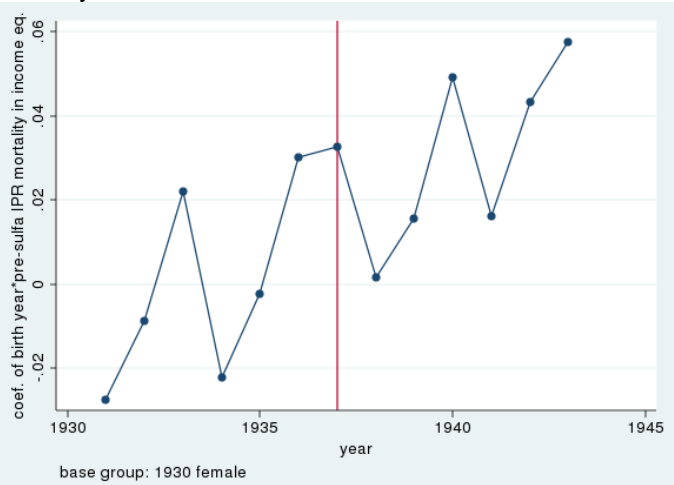

Employment

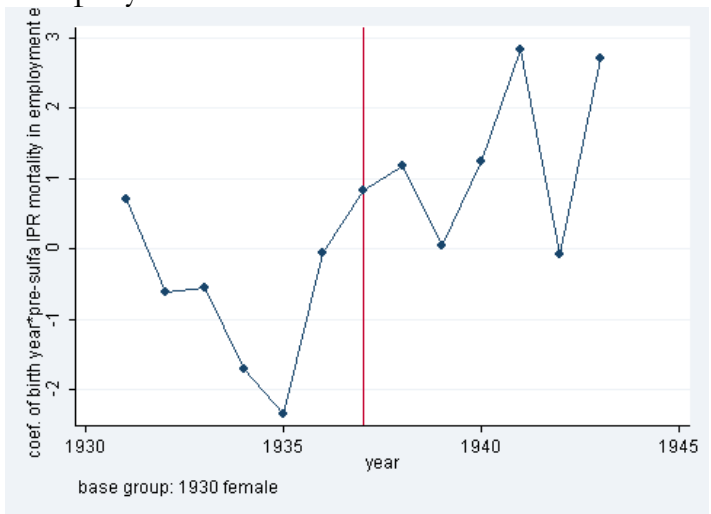

Notes: See notes to Figure 5a
Schooling

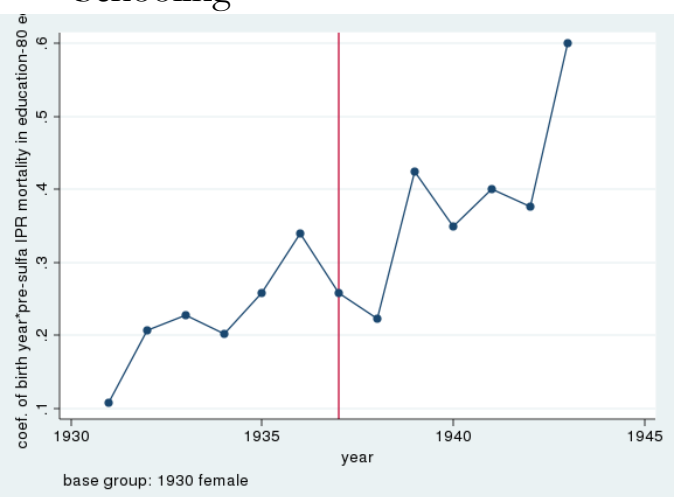

Poverty

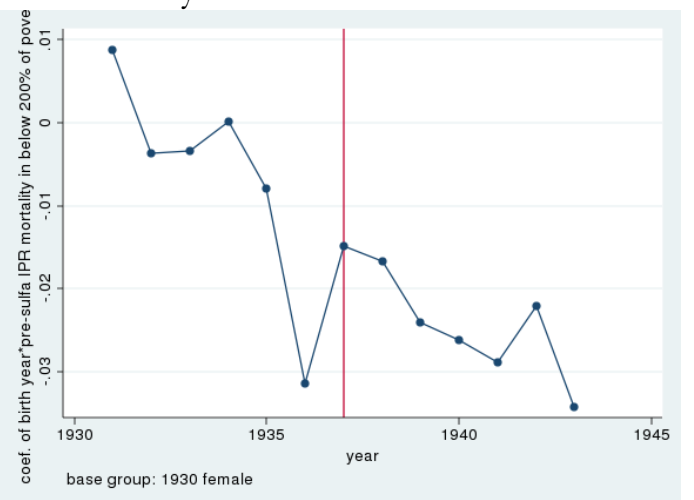


Figure 6 - Pneumonia Mortality Rates by Race, United States, 1930-1940

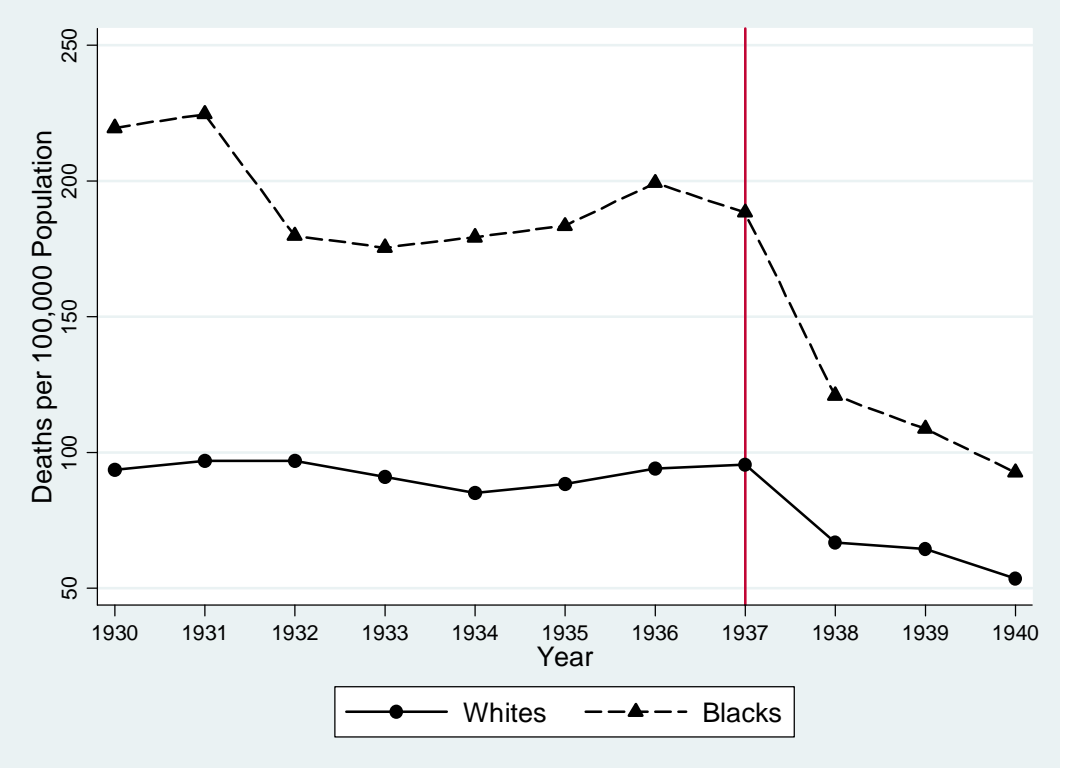

Source: US Vital Statistics 
Table 1: Main Results by Gender

\begin{tabular}{|c|c|c|c|c|c|}
\hline All Men & (1) & (2) & (3) & (4) & (5) \\
\hline $\begin{array}{l}\text { Work Limiting Disability }(\%) \\
(\mathrm{N}=3336, \text { mean }=15.86)\end{array}$ & $\begin{array}{l}-2.918^{* * *} \\
(0.599)\end{array}$ & $\begin{array}{l}-2.596 * * * \\
(0.497)\end{array}$ & $\begin{array}{l}-1.801 * * * \\
(0.590)\end{array}$ & $\begin{array}{l}-1.000 \\
(0.997)\end{array}$ & $\begin{array}{l}-2.332 * * * \\
(0.864)\end{array}$ \\
\hline $\begin{array}{l}\text { Schooling (Years) } \\
(\mathrm{N}=1130, \text { mean }=12.17)\end{array}$ & $\begin{array}{l}0.399 * * * \\
(0.105)\end{array}$ & $\begin{array}{l}0.328 * * * \\
(0.0829)\end{array}$ & $\begin{array}{l}0.350 * * * \\
(0.108)\end{array}$ & $\begin{array}{l}0.518^{* * *} \\
(0.0823)\end{array}$ & $\begin{array}{l}0.732 * * * \\
(0.150)\end{array}$ \\
\hline $\begin{array}{l}\text { Family Income (log) } \\
(\mathrm{N}=3336, \text { mean }=10.57)\end{array}$ & $\begin{array}{l}0.0387 * * * \\
(0.0138)\end{array}$ & $\begin{array}{l}0.0371 * * * \\
(0.0124)\end{array}$ & $\begin{array}{l}0.0517 * * * \\
(0.0166)\end{array}$ & $\begin{array}{l}0.0805^{* * *} \\
(0.0186)\end{array}$ & $\begin{array}{l}0.109 * * * \\
(0.0191)\end{array}$ \\
\hline $\begin{array}{l}\text { Poverty }(\%) \\
(\mathrm{N}=3336, \text { mean }=24.4)\end{array}$ & $\begin{array}{l}-2.72 * * * \\
(0.540)\end{array}$ & $\begin{array}{l}-2.71 * * * \\
(0.511)\end{array}$ & $\begin{array}{l}-1.57 * * \\
(0.768)\end{array}$ & $\begin{array}{l}-2.77 * * \\
(1.12)\end{array}$ & $\begin{array}{l}-1.61 * \\
(0.884)\end{array}$ \\
\hline $\begin{array}{l}\text { Employment }(\%) \\
(\mathrm{N}=3336, \text { mean }=67.59)\end{array}$ & $\begin{array}{l}1.565^{* * *} \\
(0.573)\end{array}$ & $\begin{array}{l}1.544 * * * \\
(0.447)\end{array}$ & $\begin{array}{l}2.539 * * * \\
(0.507)\end{array}$ & $\begin{array}{l}2.721 * * \\
(1.078)\end{array}$ & $\begin{array}{l}2.897^{*} \\
(1.606)\end{array}$ \\
\hline \multicolumn{6}{|l|}{ All Women } \\
\hline $\begin{array}{l}\text { Work Limiting Disability }(\mathbf{0}) \\
(\mathrm{N}=3378, \text { mean }=15.21)\end{array}$ & $\begin{array}{l}-2.487 * * * \\
(0.691)\end{array}$ & $\begin{array}{l}-2.016^{* * *} \\
(0.572)\end{array}$ & $\begin{array}{l}-0.366 \\
(0.660)\end{array}$ & $\begin{array}{l}1.439 * \\
(0.772)\end{array}$ & $\begin{array}{l}1.768^{* *} \\
(0.798)\end{array}$ \\
\hline $\begin{array}{l}\text { Schooling (Years) } \\
(\mathrm{N}=1137, \text { mean }=11.95)\end{array}$ & $\begin{array}{l}0.410 * * * \\
(0.0848)\end{array}$ & $\begin{array}{l}0.396^{* * * *} \\
(0.0800)\end{array}$ & $\begin{array}{l}0.197 * \\
(0.108)\end{array}$ & $\begin{array}{l}-0.0180 \\
(0.156)\end{array}$ & $\begin{array}{l}-0.0253 \\
(0.182)\end{array}$ \\
\hline $\begin{array}{l}\text { Family Income (log) } \\
(\mathrm{N}=3378, \text { mean }=10.44)\end{array}$ & $\begin{array}{l}0.0545^{* * *} \\
(0.0147)\end{array}$ & $\begin{array}{l}0.0506^{* * *} \\
(0.0125)\end{array}$ & $\begin{array}{l}0.0325^{* *} \\
(0.0135)\end{array}$ & $\begin{array}{l}-0.00507 \\
(0.0197)\end{array}$ & $\begin{array}{l}0.0364 \\
(0.0233)\end{array}$ \\
\hline $\begin{array}{l}\text { Poverty }(\%) \\
(\mathrm{N}=3378, \text { mean }=29.8)\end{array}$ & $\begin{array}{l}-3.86 * * * \\
(0.746)\end{array}$ & $\begin{array}{l}-3.28 * * * \\
(0.623)\end{array}$ & $\begin{array}{l}-1.88^{* *} \\
(0.897)\end{array}$ & $\begin{array}{l}-0.724 \\
(1.24)\end{array}$ & $\begin{array}{l}-1.70 \\
(1.39)\end{array}$ \\
\hline $\begin{array}{l}\text { Employment }(\%) \\
(\mathrm{N}=3378, \text { mean }=52.13)\end{array}$ & $\begin{array}{l}-1.018 \\
(0.651)\end{array}$ & $\begin{array}{l}-0.825 \\
(0.583)\end{array}$ & $\begin{array}{l}1.895^{* * *} \\
(0.646)\end{array}$ & $\begin{array}{l}1.022 \\
(1.112)\end{array}$ & $\begin{array}{l}-0.436 \\
(1.387)\end{array}$ \\
\hline \multicolumn{6}{|l|}{ Controls } \\
\hline Birth State, Birth Year FE & Yes & Yes & Yes & Yes & Yes \\
\hline Post*BaseRate(Control Diseases) & No & Yes & Yes & Yes & Yes \\
\hline Birth State X Birth Year Variables & No & No & Yes & Yes & Yes \\
\hline Birth State Linear Trends & No & No & No & Yes & Yes \\
\hline Birth Region X Birth Year FE & No & No & No & No & Yes \\
\hline
\end{tabular}

Notes: ${ }^{* * *}=\mathrm{p}<0.01, * *=\mathrm{p}<0.05, *=\mathrm{p}<0.10$. Robust standard errors adjusted for clustering at the birth state level in parentheses. Every row contains a different outcome and the set of controls is enlarged in moving from the first to the fifth column. Each estimate is from a different regression and is the coefficient on post $t_{t}^{*}$ base_pneumonias. The outcome variables are defined in the data appendix. FE denotes fixed effects. BaseRate(Control Diseases) includes pre-sulfa birth state averages for maternal mortality and mortality from heart disease, cancer, under 2 diarrhea, malaria and tuberculosis. Birth State X Birth Year Variables includes per capita log state income, state education expenditure, state health expenditure, school buildings, hospitals, and physicians, all by birth state and birth year. Region refers to census division region. $\mathrm{N}$ refers to the number of birth state $\mathrm{x}$ birth year $\mathrm{x}$ race $\mathrm{x}$ gender $\mathrm{x}$ census year cells. Each cell is weighted by its population in the regression analysis; unweighted regressions produce substantively similar results. 
Table 2: Additional Disability Variables by Gender

\begin{tabular}{|c|c|c|c|c|c|}
\hline & (1) & (2) & (3) & (4) & (5) \\
\hline \multicolumn{6}{|l|}{ All Men } \\
\hline $\begin{array}{l}\text { Cognitive Disability } \\
(\mathrm{N}=1102, \text { mean }=7.63)\end{array}$ & $\begin{array}{l}-1.4^{* *} \\
(0.601)\end{array}$ & $\begin{array}{l}-1.11 * * \\
(0.0546)\end{array}$ & $\begin{array}{r}-0.0315 \\
(0.732)\end{array}$ & $\begin{array}{l}-2.11 \\
(1.27)\end{array}$ & $\begin{array}{l}-2.53 \\
(1.64)\end{array}$ \\
\hline $\begin{array}{l}\text { Physical Disability } \\
(\mathrm{N}=1102, \text { mean }=21.80)\end{array}$ & $\begin{array}{l}-1.23 \\
(0.980)\end{array}$ & $\begin{array}{l}-0.93 \\
(1.01)\end{array}$ & $\begin{array}{l}-0.253 \\
(1.20)\end{array}$ & $\begin{array}{r}-0.789 \\
(2.59)\end{array}$ & $\begin{array}{l}1.07 \\
(2.24)\end{array}$ \\
\hline \multicolumn{6}{|l|}{ All Women } \\
\hline $\begin{array}{l}\text { Cognitive Disability } \\
(\mathrm{N}=1118, \text { mean }=6.97)\end{array}$ & $\begin{array}{l}-0.903 \\
(0.605)\end{array}$ & $\begin{array}{l}-0.731 \\
(0.520)\end{array}$ & $\begin{array}{c}0.665 \\
(0.768)\end{array}$ & $\begin{array}{l}2.02^{*} \\
(1.20)\end{array}$ & $\begin{array}{c}1.15 \\
(1.31)\end{array}$ \\
\hline $\begin{array}{l}\text { Physical Disability } \\
(\mathrm{N}=1118, \text { mean }=22.70)\end{array}$ & $\begin{array}{c}-1.04 \\
(0.886)\end{array}$ & $\begin{array}{l}-0.623 \\
(0.882)\end{array}$ & $\begin{array}{l}0.596 \\
(1.11)\end{array}$ & $\begin{array}{l}3.47^{* *} \\
(1.52)\end{array}$ & $\begin{array}{c}3.13 \\
(2.01)\end{array}$ \\
\hline See Notes to Table 1. & & & & & \\
\hline
\end{tabular}




\begin{tabular}{|c|c|c|c|c|c|c|c|c|c|c|c|}
\hline & (1) & (2) & (3) & (4) & (5) & & (1) & (2) & (3) & (4) & (5) \\
\hline White Men & & & & & & Black Men & & & & & \\
\hline Work Limiting Disability (\%) & $-3.161 * * *$ & $-2.890 * * *$ & $-2.089 * * *$ & -1.327 & $-3.165^{* * *}$ & Work Limiting Disability (\%) & -0.187 & 0.913 & 0.756 & -0.840 & 0.713 \\
\hline$(\mathrm{N}=1914$, mean $=13.44)$ & $(0.650)$ & $(0.561)$ & $(0.651)$ & $(1.055)$ & $(0.806)$ & $(\mathrm{N}=1422$, mean $=19.12)$ & $(1.547)$ & $(1.284)$ & $(1.598)$ & $(3.499)$ & $(4.095)$ \\
\hline Schooling (Years) & $0.401^{* * *}$ & $0.336 * * *$ & $0.402^{* * *}$ & $0.567 * * *$ & $0.865^{* * *}$ & Schooling (Years) & 0.380 & 0.168 & -0.153 & -0.173 & -0.186 \\
\hline$(\mathrm{N}=638$, mean $=12.58)$ & $(0.107)$ & $(0.0863)$ & $(0.108)$ & $(0.101)$ & $(0.181)$ & $(\mathrm{N}=492$, mean $=11.54)$ & $(0.302)$ & $(0.245)$ & $(0.249)$ & $(0.201)$ & $(0.225)$ \\
\hline Family Income (log) & $0.0351^{* *}$ & $0.0324^{* *}$ & $0.0511^{* * *}$ & $0.0703^{* * *}$ & $0.111^{* * *}$ & Family Income (log) & 0.0792 & 0.0599 & 0.0110 & 0.124 & 0.0223 \\
\hline$(\mathrm{N}=1914$, mean $=10.71)$ & $(0.0146)$ & $(0.0127)$ & $(0.0176)$ & $(0.0229)$ & $(0.0306)$ & $(\mathrm{N}=1422$, mean $=10.39)$ & $(0.0535)$ & $(0.0483)$ & $(0.0597)$ & $(0.111)$ & $(0.0880)$ \\
\hline Poverty (\%) & $-2.24 * * *$ & $-2.17 * * *$ & -0.863 & $-2.27 *$ & -1.22 & Poverty (\%) & $-8.06 * * *$ & $-6.40 * * *$ & -1.81 & $-5.72^{* *}$ & -3.50 \\
\hline$(\mathrm{N}=1914$, mean $=16.70)$ & $(0.565)$ & $(0.530)$ & $(0.804)$ & $(1.14)$ & $(0.893)$ & $(\mathrm{N}=1422$, mean $=34.70)$ & $(2.36)$ & (2.03) & $(1.80)$ & $(2.59)$ & $(2.23)$ \\
\hline Employment (\%) & $1.421 * *$ & $1.388^{* * *}$ & $2.469 * * *$ & $2.260 *$ & 2.855 & Employment (\%) & 3.183 & 1.669 & -1.583 & 3.315 & 0.00261 \\
\hline$(\mathrm{N}=1914$, mean $=72.52)$ & $(0.636)$ & $(0.504)$ & $(0.564)$ & $(1.204)$ & $(2.004)$ & $(\mathrm{N}=1422$, mean $=60.69)$ & $(2.687)$ & $(2.623)$ & $(2.378)$ & $(4.328)$ & $(3.778)$ \\
\hline Cognitive Disability (\%) & -1.07 & -0.767 & 0.203 & -1.31 & -1.32 & Cognitive Disability (\%) & $-5.26^{* * *}$ & $-5.3^{* * *}$ & $-4.06^{*}$ & -6.55 & -3.56 \\
\hline$(\mathrm{N}=638$, mean $=5.99)$ & $(0.658)$ & $(0.622)$ & $(0.750)$ & $(1.26)$ & $(1.89)$ & $(\mathrm{N}=464$, mean $=9.89)$ & $(1.55)$ & $(1.78)$ & $(2.27)$ & $(6.07)$ & $(6.23)$ \\
\hline Physical Disability (\%) & -0.932 & -0.613 & 0.132 & -0.28 & 1.46 & Physical Disability (\%) & $-4.75^{*}$ & $-5.66^{*}$ & 1.38 & -1.65 & 1.4 \\
\hline$(\mathrm{N}=638$, mean $=18.70)$ & (1.03) & $(1.09)$ & $(1.29)$ & $(2.87)$ & $(2.55)$ & $(\mathrm{N}=464$, mean $=26.2)$ & $(2.54)$ & $(3.07)$ & $(4.67)$ & $(5.81)$ & $(8.01)$ \\
\hline
\end{tabular}


Table 4: Results for Women by Race

\begin{tabular}{|c|c|c|c|c|c|c|c|c|c|c|c|}
\hline & (1) & (2) & (3) & (4) & (5) & & (1) & (2) & (3) & (4) & (5) \\
\hline White Women & & & & & & Black Women & & & & & \\
\hline $\begin{array}{l}\text { Work Limiting Disability }(\%) \\
(\mathrm{N}=1914, \text { mean }=11.78)\end{array}$ & $\begin{array}{c}-2.736^{* * *} \\
(0.761)\end{array}$ & $\begin{array}{c}-2.288^{* * *} \\
(0.611)\end{array}$ & $\begin{array}{l}-0.618 \\
(0.699)\end{array}$ & $\begin{array}{l}1.510^{*} \\
(0.896)\end{array}$ & $\begin{array}{l}2.225^{*} \\
(1.146)\end{array}$ & $\begin{array}{l}\text { Work Limiting Disability }(\%) \\
(\mathrm{N}=1464, \text { mean }=19.70)\end{array}$ & $\begin{array}{l}-0.171 \\
(1.530)\end{array}$ & $\begin{array}{l}0.0956 \\
(1.457)\end{array}$ & $\begin{array}{l}1.406 \\
(1.384)\end{array}$ & $\begin{array}{c}1.145 \\
(3.015)\end{array}$ & $\begin{array}{l}-0.981 \\
(2.214)\end{array}$ \\
\hline $\begin{array}{l}\text { Schooling (Years) } \\
(\mathrm{N}=638, \text { mean }=12.17)\end{array}$ & $\begin{array}{c}0.409 * * * \\
(0.0854)\end{array}$ & $\begin{array}{l}0.412 * * * \\
(0.0774)\end{array}$ & $\begin{array}{r}0.261 * * * \\
(0.0913)\end{array}$ & $\begin{array}{l}-0.0197 \\
(0.177)\end{array}$ & $\begin{array}{l}-0.0369 \\
(0.239)\end{array}$ & $\begin{array}{l}\text { Schooling (Years) } \\
(N=499, \text { mean }=11.64)\end{array}$ & $\begin{array}{c}0.415 \\
(0.345)\end{array}$ & $\begin{array}{c}0.271 \\
(0.281)\end{array}$ & $\begin{array}{l}-0.198 \\
(0.363)\end{array}$ & $\begin{array}{l}-0.220 \\
(0.293)\end{array}$ & $\begin{array}{l}-0.381 \\
(0.374)\end{array}$ \\
\hline $\begin{array}{l}\text { Family Income }(\log ) \\
(\mathrm{N}=1914, \text { mean }=10.60)\end{array}$ & $\begin{array}{c}0.0522^{* * *} \\
(0.0163)\end{array}$ & $\begin{array}{c}0.0502^{* * *} \\
(0.0138)\end{array}$ & $\begin{array}{c}0.0360^{* *} \\
(0.0155)\end{array}$ & $\begin{array}{l}-0.0175 \\
(0.0223)\end{array}$ & $\begin{array}{c}0.0212 \\
(0.0335)\end{array}$ & $\begin{array}{l}\text { Family Income }(\log ) \\
(\mathrm{N}=1464, \text { mean }=9.39)\end{array}$ & $\begin{array}{l}0.0760^{*} \\
(0.0418)\end{array}$ & $\begin{array}{c}0.0470 \\
(0.0389)\end{array}$ & $\begin{array}{c}0.0190 \\
(0.0389)\end{array}$ & $\begin{array}{c}0.0818 \\
(0.0652)\end{array}$ & $\begin{array}{r}0.118^{*} \\
(0.0689\end{array}$ \\
\hline $\begin{array}{l}\text { Poverty }(\%) \\
(\mathrm{N}=1914, \text { mean }=20.4)\end{array}$ & $\begin{array}{l}-3.85 * * * \\
(0.795)\end{array}$ & $\begin{array}{c}-3.27 * * * \\
(0.652)\end{array}$ & $\begin{array}{l}-1.93^{*} \\
(0.971)\end{array}$ & $\begin{array}{r}-0.885 \\
(1.41)\end{array}$ & $\begin{array}{l}-2.09 \\
(1.59)\end{array}$ & $\begin{array}{l}\text { Poverty }(\%) \\
(\mathrm{N}=1464, \text { mean }=42.1)\end{array}$ & $\begin{array}{l}-3.94 * \\
(2.15)\end{array}$ & $\begin{array}{l}-2.51 \\
(2.04)\end{array}$ & $\begin{array}{r}-0.899 \\
(1.93)\end{array}$ & $\begin{array}{c}-0.0978 \\
(2.34)\end{array}$ & $\begin{array}{r}-0.949 \\
(3.36)\end{array}$ \\
\hline $\begin{array}{l}\text { Employment }(\%) \\
(\mathrm{N}=1914, \text { mean }=52.06)\end{array}$ & $\begin{array}{c}-1.536^{* *} \\
(0.681)\end{array}$ & $\begin{array}{c}-1.353^{* *} \\
(0.629)\end{array}$ & $\begin{array}{l}1.772^{* *} \\
(0.676)\end{array}$ & $\begin{array}{c}1.577 \\
(1.134)\end{array}$ & $\begin{array}{l}-0.0399 \\
(1.638)\end{array}$ & $\begin{array}{l}\text { Employment }(\%) \\
(\mathrm{N}=1464, \text { mean }=52.22)\end{array}$ & $\begin{array}{l}3.786 * * \\
(1.558)\end{array}$ & $\begin{array}{c}3.736^{* * * *} \\
(1.176)\end{array}$ & $\begin{array}{l}1.389 \\
(2.044)\end{array}$ & $\begin{array}{l}-4.409 \\
(2.837)\end{array}$ & $\begin{array}{l}-2.423 \\
(2.108)\end{array}$ \\
\hline $\begin{array}{l}\text { Cognitive Disability (\%) } \\
(\mathrm{N}=638, \text { mean }=5.00)\end{array}$ & $\begin{array}{l}-1.09 * \\
(0.626)\end{array}$ & $\begin{array}{l}-0.88^{*} \\
(0.515)\end{array}$ & $\begin{array}{c}0.575 \\
(0.696)\end{array}$ & $\begin{array}{c}1.7 \\
(1.26)\end{array}$ & $\begin{array}{l}0.773 \\
(1.64)\end{array}$ & $\begin{array}{l}\text { Cognitive Disability }(\%) \\
(\mathrm{N}=480, \text { mean }=9.59)\end{array}$ & $\begin{array}{l}0.935 \\
(1.77)\end{array}$ & $\begin{array}{l}1.23 \\
(1.81)\end{array}$ & $\begin{array}{c}2.23 \\
(2.70)\end{array}$ & $\begin{array}{l}1.75 \\
(3.43)\end{array}$ & $\begin{array}{l}0.543 \\
(3.37)\end{array}$ \\
\hline $\begin{array}{l}\text { Physical Disability (\%) } \\
(\mathrm{N}=638, \text { mean }=18.2)\end{array}$ & $\begin{array}{l}-0.891 \\
(0.893) \\
\end{array}$ & $\begin{array}{l}-0.477 \\
(0.860)\end{array}$ & $\begin{array}{r}1.44 \\
(1.07) \\
\end{array}$ & $\begin{array}{r}3.53^{* *} \\
(1.33) \\
\end{array}$ & $\begin{array}{l}3.62 * \\
(2.13) \\
\end{array}$ & $\begin{array}{l}\text { Physical Disability (\%) } \\
(\mathrm{N}=480, \text { mean }=28.5)\end{array}$ & $\begin{array}{c}-2.5 \\
(3.13) \\
\end{array}$ & $\begin{array}{l}-2.71 \\
(3.70) \\
\end{array}$ & $\begin{array}{l}-1.95 \\
(3.44) \\
\end{array}$ & $\begin{array}{l}11.9 \\
(9.71)\end{array}$ & $\begin{array}{r}6.37 \\
(7.75) \\
\end{array}$ \\
\hline Controls & & & & & & Controls & & & & & \\
\hline Birth State, Birth Year FE & Yes & Yes & Yes & Yes & Yes & Birth State, Birth Year FE & Yes & Yes & Yes & Yes & Yes \\
\hline Post*BaseRate(Control Diseases) & No & Yes & Yes & Yes & Yes & Post*BaseRate(Control Diseases) & No & Yes & Yes & Yes & Yes \\
\hline Birth State X Birth Year Variables & No & No & Yes & Yes & Yes & Birth State X Birth Year Variables & No & No & Yes & Yes & Yes \\
\hline Birth State Linear Trends & No & No & No & Yes & Yes & Birth State Linear Trends & No & No & No & Yes & Yes \\
\hline Birth Region X Birth Year FE & No & No & No & No & Yes & Birth Region X Birth Year FE & No & No & No & No & Yes \\
\hline
\end{tabular}


Table 5: Triple Difference Estimator by Race and Gender

\begin{tabular}{|c|c|c|c|c|c|}
\hline & Work Disability & Schooling & Family Income & Poverty & Employment \\
\hline $\begin{array}{l}\text { All Men } \\
(\mathrm{N}=3336)\end{array}$ & $\begin{array}{c}-2.332 * * * \\
(0.864)\end{array}$ & $\begin{array}{l}0.254 * * * \\
(0.0942)\end{array}$ & $\begin{array}{l}0.109 * * * \\
(0.0191)\end{array}$ & $\begin{array}{l}-1.61 * \\
(0.884)\end{array}$ & $\begin{array}{l}2.897^{*} \\
(1.606)\end{array}$ \\
\hline $\begin{array}{l}\text { All Women } \\
(\mathrm{N}=6585)\end{array}$ & $\begin{array}{l}-0.867 \\
(1.202)\end{array}$ & $\begin{array}{l}0.357^{*} \\
(0.179)\end{array}$ & $\begin{array}{c}0.0618 * * * \\
(0.0183)\end{array}$ & $\begin{array}{l}-2.34 \\
(1.51)\end{array}$ & $\begin{array}{c}4.484^{* * *} \\
(1.270)\end{array}$ \\
\hline $\begin{array}{l}\text { White Men } \\
(\mathrm{N}=3807)\end{array}$ & $\begin{array}{l}-0.847 \\
(1.173)\end{array}$ & $\begin{array}{c}0.604 * * * \\
(0.153)\end{array}$ & $\begin{array}{c}0.125^{* * *} \\
(0.0276)\end{array}$ & $\begin{array}{l}0.771 \\
(1.50)\end{array}$ & $\begin{array}{l}1.416 \\
(1.091)\end{array}$ \\
\hline $\begin{array}{l}\text { White Women } \\
(\mathrm{N}=3807)\end{array}$ & $\begin{array}{l}-0.419 \\
(1.178)\end{array}$ & $\begin{array}{c}0.373^{* *} \\
(0.165)\end{array}$ & $\begin{array}{c}0.0551 * * \\
(0.0207)\end{array}$ & $\begin{array}{l}-1.64 \\
(1.40)\end{array}$ & $\begin{array}{c}4.653^{* * *} \\
(1.342)\end{array}$ \\
\hline $\begin{array}{l}\text { Black Men } \\
(\mathrm{N}=2665)\end{array}$ & $\begin{array}{c}-7.288^{* * *} \\
(2.648)\end{array}$ & $\begin{array}{c}0.567 \\
(0.515)\end{array}$ & $\begin{array}{c}0.0899 \\
(0.0818)\end{array}$ & $\begin{array}{l}-4.31 \\
(2.94)\end{array}$ & $\begin{array}{c}4.023 \\
(3.509)\end{array}$ \\
\hline $\begin{array}{l}\text { Black Women } \\
(\mathrm{N}=2782)\end{array}$ & $\begin{array}{l}-2.558 \\
(2.937)\end{array}$ & $\begin{array}{c}0.222 \\
(0.380)\end{array}$ & $\begin{array}{c}0.0846 \\
(0.0637)\end{array}$ & $\begin{array}{l}-5.52 \\
(3.63)\end{array}$ & $\begin{array}{c}1.385 \\
(2.360)\end{array}$ \\
\hline
\end{tabular}

See Notes to Table 1 and Appendix Figure 1. The triple difference term is

post*base_pneumonia*treated where post and base_pneumonia are defined as in the baseline model and treated is defined as 1 if first exposed to sulfa at age 0-1 and as 0 if first exposed at age 10-15. 
APPENDIX- NOT FOR PUBLICATION

Appendix Figures

A1: Triple Difference: Treatment Definitions on Cohort and Age of Exposure

Age at time of exposure

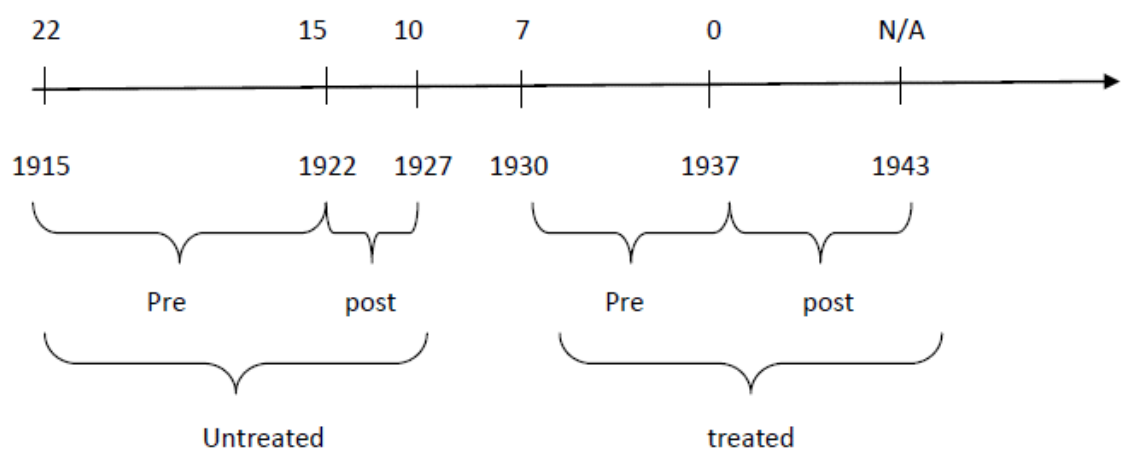

Notes: Refer section 5.4 of the text. 
Figure A2. All Men: Birth-Year Specific Coefficients on Pre-Intervention Mortality Rates for Pneumonia and

\section{Heart Disease}

Work Limiting Disability

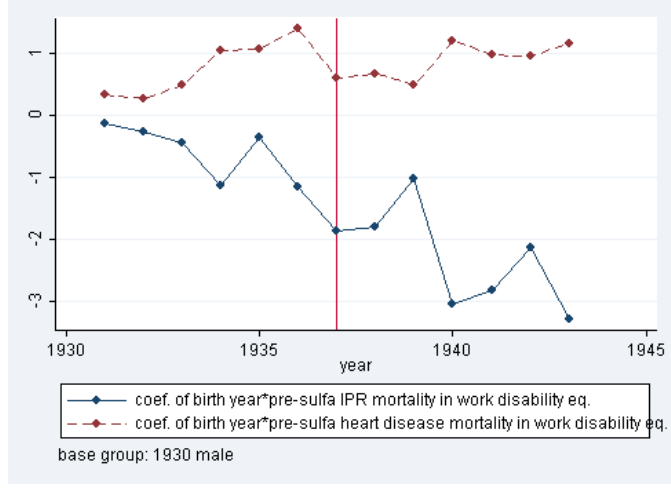

Family Income

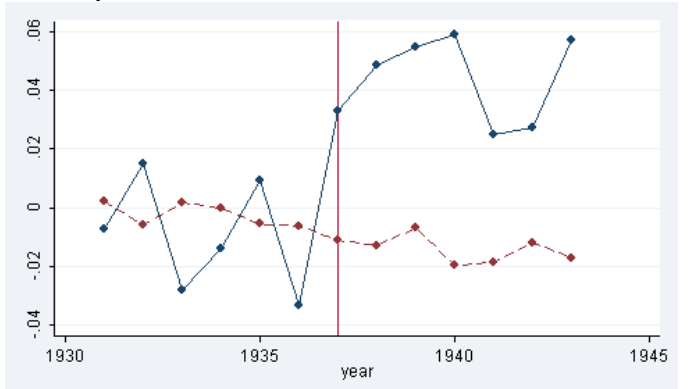

—— coef. of birth yeartpre-sulfa IPR mortality in income eq.

- - - coef. of birth year"pre-sulfa heart disease mortality in income eq. base group: 1930 male
Schooling

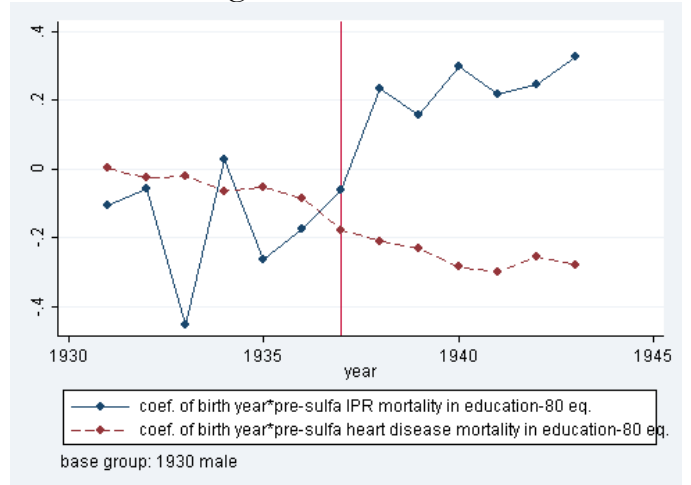

Poverty

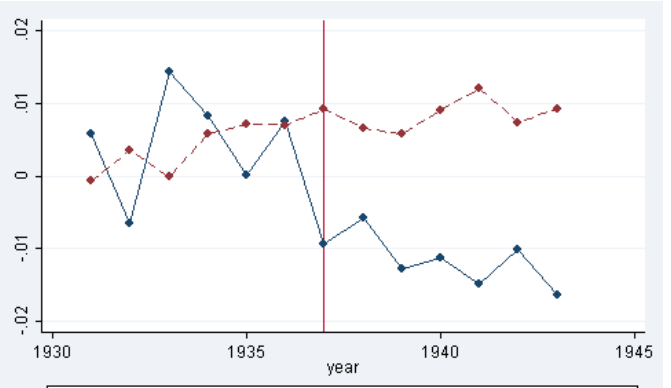

$\longrightarrow$ - coef. of birth yeartpre-sulfa IPR mortality in below $200 \%$ of poverty eq. $-\rightarrow--$ coef. of birth yearpre-sulfa heart disease mortality in below $200 \%$ of pove base group: 1930 male

Employment

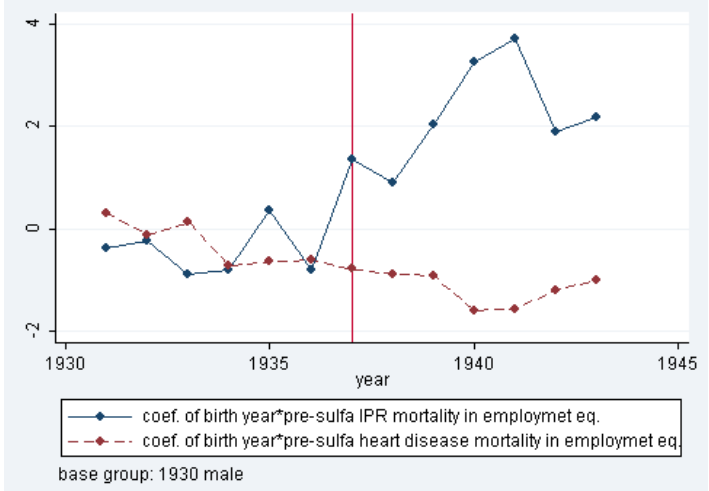

Notes: See Notes to Figure 5a. Pneumonia was (directly) treatable with sulfa drugs, heart disease was not. 
Figure A3. All Women: Birth-Year Specific Coefficients on Pre-Intervention Mortality Rates for Pneumonia and Heart Disease

Work Limiting Disability

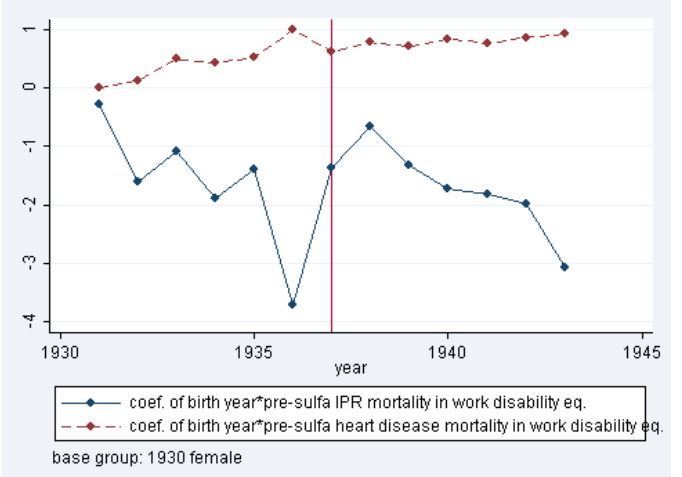

Family Income

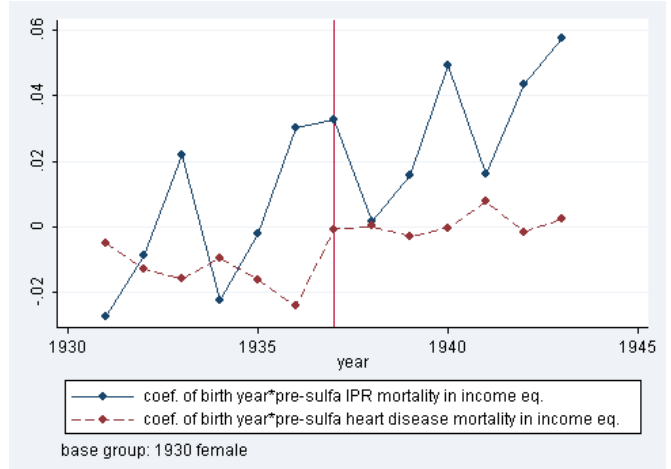

Employment

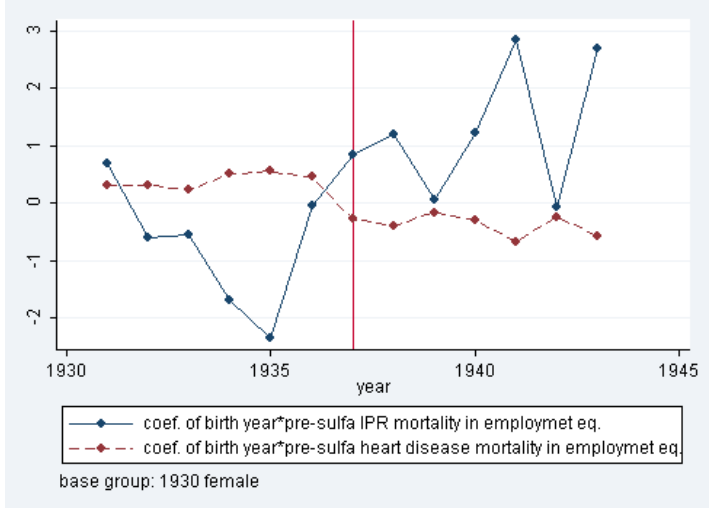

Notes: See Notes to Figure A2.
Schooling

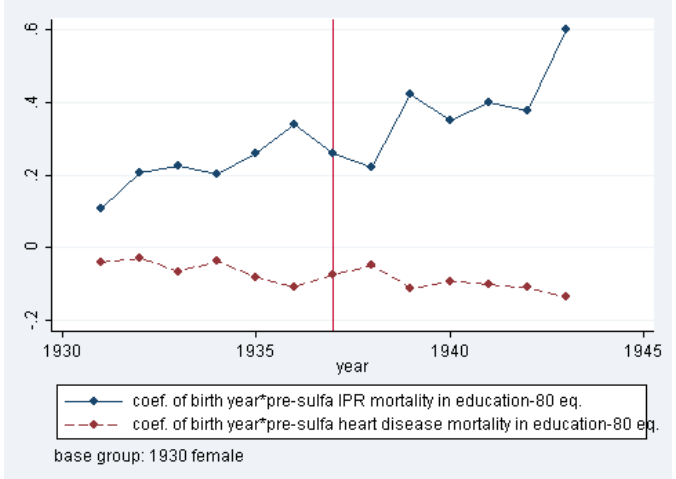

Poverty

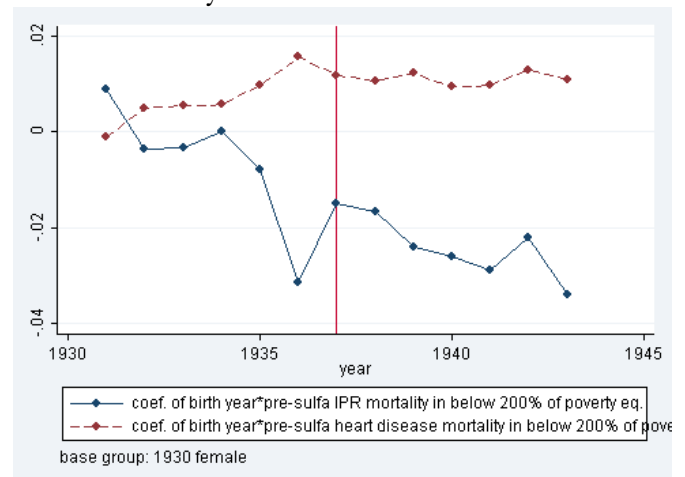


Appendix Tables

Table A1: Descriptive Statistics

\begin{tabular}{|c|c|c|c|c|c|c|}
\hline Census Variables & Men & Women & White Men & White Women & Black Men & Black Women \\
\hline Schooling & $12.14(1.03)$ & $11.94(0.75)$ & $12.58(0.78)$ & $12.17(0.61)$ & $11.54(1.04)$ & $11.64(0.80)$ \\
\hline Log Family Income & $10.58(0.44)$ & $10.45(0.42)$ & $10.72(0.38)$ & $10.61(0.33)$ & $10.39(0.44)$ & $10.23(0.43)$ \\
\hline Poverty & $24.06(13.26)$ & $29.23(15.20)$ & $16.56(5.22)$ & $20.10(6.01)$ & $34.76(13.89)$ & $41.93(14.99)$ \\
\hline \% Employed & $67.94(13.26)$ & $52.37(19.05)$ & $72.81(22.88)$ & $52.35(17.24)$ & $60.99(23.60)$ & $52.40(21.33)$ \\
\hline$\%$ Work Disability & $15.75(8.91)$ & $14.93(9.30)$ & $13.32(5.08)$ & $11.63(4.45)$ & $19.22(11.63)$ & $19.53(11.97)$ \\
\hline \% Cognitive Difficulty & $7.55(6.77)$ & $6.84(6.40)$ & $5.99(3.87)$ & $4.95(2.18)$ & $9.83(9.08)$ & $9.52(8.95)$ \\
\hline$\%$ Physical Difficulty & $21.53(10.80)$ & $22.24(10.51)$ & $18.48(5.64)$ & $17.97(4.92)$ & $26.013(0.61)$ & $28.30(13.04)$ \\
\hline
\end{tabular}

Birth State Baseline Mortality Rates (Per Thousand, $N=48$ States)

\begin{tabular}{lc}
\hline Pneumonia & $1.06(0.19)$ \\
Tuberculosis & $0.64(0.37)$ \\
Diarrhea & $8.22(5.64)$ \\
Cancer & $0.96(0.31)$ \\
Heart Disease & $2.09(0.63)$ \\
Maternal mortality & $6.35(1.24)$ \\
Malaria & $0.032(0.074)$
\end{tabular}

Birth State X Birth Year Socioeconomic Variables $(\mathrm{N}=669)$

\begin{tabular}{lc}
\hline Log Income Per Capita & $6.18(0.50)$ \\
Log Hospitals Per 1,000 & $-2.83(0.46)$ \\
Log Physicians Per 1,000 & $0.14(0.36)$ \\
Log Schools Per 1,000 & $0.72(0.65)$ \\
Log Educational Spending Per & $4.27(0.79)$ \\
Capita &
\end{tabular}

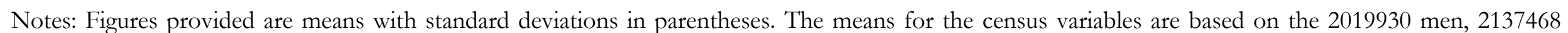

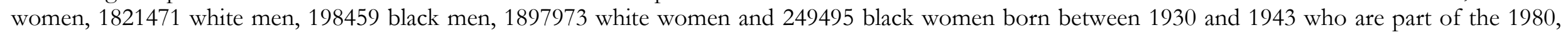

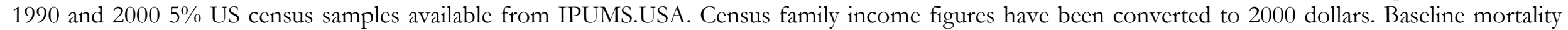

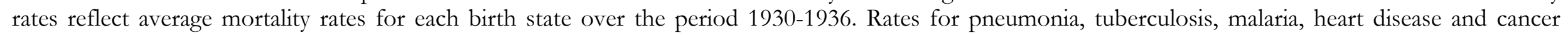
reflect deaths per 1,000 total population. Diarrhea and maternal mortality rates are per 1,000 live births. 
Table A2: Placebo Intervention in 1934

\begin{tabular}{lccccc}
\hline \multicolumn{5}{c}{ Table A2: Placebo Intervention in 1934 } \\
\hline & $\begin{array}{c}\text { Work } \\
\text { Disability }\end{array}$ & Education & Family Income & Poverty & Employment \\
\hline All Men & $1.816^{* *}$ & -0.177 & -0.000609 & 1.16 & $-2.216^{* *}$ \\
$(\mathrm{~N}=3,554)$ & $(0.682)$ & $(0.111)$ & $(0.0194)$ & $(0.935)$ & $(1.052)$ \\
& & & & & \\
All Women & 0.189 & $-0.213^{* * *}$ & -0.0209 & 0.504 & -1.363 \\
$(\mathrm{~N}=3,582)$ & $(0.682)$ & $(0.0500)$ & $(0.0207)$ & $(0.908)$ & $(0.853)$ \\
& & & & & \\
White Men & $1.614^{*}$ & -0.176 & 0.00811 & 0.758 & -1.532 \\
$(\mathrm{~N}=1,914)$ & $(0.874)$ & $(0.118)$ & $(0.0249)$ & $(1.08)$ & $(1.111)$ \\
& & & & & \\
White & & & & & \\
Women & -0.267 & $-0.279 * * *$ & -0.0213 & -0.0257 & -1.268 \\
$(\mathrm{~N}=1,914)$ & $(0.581)$ & $(0.0594)$ & $(0.0222)$ & $(1.15)$ & $(1.069)$ \\
& & & & & \\
Black Men & 2.825 & 0.0500 & -0.0312 & 1.90 & -4.443 \\
$(\mathrm{~N}=1,640)$ & $(2.426)$ & $(0.212)$ & $(0.0598)$ & $(2.91)$ & $(2.675)$ \\
& & & & & \\
Black Women & $5.215^{* *}$ & $0.202^{*}$ & -0.0560 & 4.26 & $-4.435^{* *}$ \\
$(\mathrm{~N}=1,668)$ & $(2.236)$ & $(0.103)$ & $(0.0637)$ & $(2.70)$ & $(1.994)$ \\
& & & & & \\
\hline
\end{tabular}

See Notes to Table 1. The specification is that in column 5 of Table 1. The placebo involves defining post as 1 for cohorts born in and after 1934 instead of in and after 1937. 


\begin{tabular}{|l|l|l|}
\hline \multicolumn{3}{|c|}{ Table A3: Selective Migration Post-Sulfa } \\
\hline & Fixed effects & Add controls \\
\hline All & $0.100^{*}$ & 0.0308 \\
& $(0.0518)$ & $(0.0713)$ \\
\hline White & $0.119 *$ & 0.0598 \\
& $(0.0557)$ & $(0.0776)$ \\
\hline Black & 0.217 & 0.0720 \\
& $(0.207)$ & $(0.281)$ \\
\hline
\end{tabular} \mid $\begin{aligned} & \text { Notes: See section 5.4 of the text. The dependent variable is the log of the population aged 20-40. } \\
& \text { Each cell contains the coefficient on post*base_pneumonia from a separate regression. Data are from US } \\
& \text { census microdata files for 1930 and 1940, collapsed to the state level. There are 48 states and the } \\
& \text { maximum number of observations per state is three, denoting population in 1930, 1935 and 1940. The } \\
& \text { estimation sample contains N=144. }\end{aligned}$


Table A4: Removing the influenza uptick of 1935-1936

\begin{tabular}{lccccc}
\hline & Work Disability & Education & Family Income & Poverty & Employment \\
\hline All Men & $-3.037^{* *}$ & $0.344^{* *}$ & $0.130^{* * *}$ & -1.80 & $3.298^{*}$ \\
$(\mathrm{~N}=2,851)$ & $(1.149)$ & $(0.154)$ & $(0.0346)$ & $(1.24)$ & $(1.959)$ \\
& & & & & \\
All Women & $2.081^{* *}$ & -0.0538 & 0.0432 & -1.67 & 2.325 \\
$(\mathrm{~N}=2,879)$ & $(1.004)$ & $(0.0914)$ & $(0.0287)$ & $(1.66)$ & $(1.580)$ \\
White Men & $-3.784^{* * *}$ & $0.342^{* *}$ & $0.125^{* * *}$ & -0.546 & 2.851 \\
$(\mathrm{~N}=1,632)$ & $(1.192)$ & $(0.162)$ & $(0.0441)$ & $(1.27)$ & $(2.353)$ \\
White Women & 2.600 & -0.0258 & 0.0614 & -2.35 & $3.482^{*}$ \\
$(\mathrm{~N}=1,632)$ & $(1.663)$ & $(0.118)$ & $(0.0412)$ & $(2.01)$ & $(1.938)$ \\
Black Men & 0.181 & 0.267 & 0.124 & $-9.42^{* *}$ & 5.634 \\
$(\mathrm{~N}=1,219)$ & $(4.773)$ & $(0.257)$ & $(0.0845)$ & $(3.96)$ & $(4.893)$ \\
Black Women & 0.766 & -0.0860 & -0.0499 & 1.98 & -6.742 \\
$(\mathrm{~N}=1,247)$ & $(4.071)$ & $(0.274)$ & $(0.130)$ & $(5.66)$ & $(5.223)$ \\
& & & & & \\
\hline
\end{tabular}

See Notes to Table 1. This is the specification in column 5 of Table 1. It is re-estimated removing the years 1935-36 from the sample as there was an influenza epidemic in these years: see Jayachandran et al. 2010. 
Table A5: Removing the Southern States

\begin{tabular}{lccccc}
\hline & $\begin{array}{c}\text { Work } \\
\text { Disability }\end{array}$ & Education & Family Income & Poverty & Employment \\
\hline All Men & -1.687 & $0.180^{*}$ & $0.0959^{* * *}$ & $-1.87^{*}$ & 2.324 \\
$(\mathrm{~N}=2,133)$ & $(1.278)$ & $(0.102)$ & $(0.0174)$ & $(0.925)$ & $(1.654)$ \\
& & & & & \\
All Women & 0.859 & $-0.176^{*}$ & 0.0129 & -2.32 & 1.464 \\
$(\mathrm{~N}=2,142)$ & $(0.953)$ & $(0.0879)$ & $(0.0193)$ & $(1.59)$ & $(1.921)$ \\
White Men & $-2.770^{* *}$ & $0.191^{* *}$ & $0.0909^{* *}$ & -1.22 & 2.956 \\
$(\mathrm{~N}=1,158)$ & $(1.057)$ & $(0.0917)$ & $(0.0373)$ & $(0.922)$ & $(2.327)$ \\
& & & & & \\
White Women & 2.198 & -0.158 & -0.0213 & $-2.99 *$ & 2.041 \\
$(\mathrm{~N}=1,158)$ & $(1.667)$ & $(0.0990)$ & $(0.0310)$ & $(1.76)$ & $(2.510)$ \\
& & & & & \\
Black Men & 0.145 & 0.109 & 0.0254 & $-3.65 * *$ & -3.192 \\
$(\mathrm{~N}=975)$ & $(4.167)$ & $(0.208)$ & $(0.0937)$ & $(1.75)$ & $(3.113)$ \\
& & & & & \\
Black Women & -3.946 & $-0.361^{* *}$ & 0.0968 & -0.0720 & -3.089 \\
$(\mathrm{~N}=984)$ & $(2.397)$ & $(0.147)$ & $(0.0719)$ & $(3.78)$ & $(2.198)$
\end{tabular}

See Notes to Table 1. This is the specification in column 5 of Table 1. It is re-estimated on a sample that excludes the Southern states, namely, Alabama, Arkansas, Delaware, District of Columbia, Florida, Georgia, Kentucky, Louisiana, Maryland, Mississippi, North Carolina, Oklahoma, South Carolina, Tennessee, Texas, Virginia, West Virginia. 


\section{Data Appendix}

Outcomes - These were all taken from the 1980 5\%, 1990 5\% and 2000 5\% United States Census Microdata samples (available via IPUMS-USA, http://usa.ipums.org/usa/). These data are publicly available via the Integrated Public Use Microdata Series - USA project (Ruggles et al., 2010). We aggregated all data into birth state $\mathrm{X}$ birth cohort $\mathrm{X}$ race (white and other) X gender X census year cells. Data on the 2,019,930 men, 2,137,468 women, 1821,471 white men, 198,459 black men, 1,897,973 white women and 248,495 black women in the three census samples who were born between 1930 and 1943 (the period of interest in the study) were used to create cell level means.

Schooling - Represents the highest grade of schooling completed. This variable was constructed using the IPUMS variable HIGRADE. The 1980 census provides explicitly designated years of schooling for the pre-high school years. Later census files group those completing ninth grade and under into three categories and top code those who progress beyond college. Since schooling was likely completed before the age of 30 for most sample individuals, we show estimates that use only the 1980 census data for this variable.

Logged Total Family Income - From the IPUMS variable FTOTINC. Describes the (nominal) total pre-tax money income earned by the respondent's family unit in the previous calendar year.

Poverty- An indicator for whether family income is $200 \%$ below the federal household poverty line or lower.

Employed - Uses the IPUMS variable EMPSTAT, which distinguishes between current employment, unemployment and not being in the labor force. For each individual, we set employment $=1$ if the individual reports current employment and 0 otherwise.

Work Limiting Disability - The IPUMS variable DISABWRK Indicates a physical or mental health condition that causes difficulty working, limits the amount or type of work, or prevents working altogether. The disability cannot be transient (e.g., pregnancy) and must have been present for at least six month prior to survey. We coded any limitation in the ability to work (either certain limitations or the inability to work altogether) as representing disability.

Cognitive Disability - From the IPUMS variable DIFFREM, which denotes whether an individual has difficulty with cognitive tasks due to a physical or mental illness. This variable is only available in the 2000 census.

Physical Disability - From the IPUMS variable DIFFPHYS. Denotes if the respondent has a condition that limits basic tasks of daily living that involve movement (walking, running, lifting, etc). This variable is only available in the 2000 census.

Mortality rates by cause of death - State time series data on influenza and pneumonia, under-2 diarrheal, heart disease, cancer, and tuberculosis mortality, as well as the maternal mortality ratio, were taken from various volumes of the US Vital Statistics (Grove, 1968; 
Linder, 1947; United States Bureau of the Census, 1930-1943). We also made use of US Vital Statistics data collected by Grant Miller and Seema Jayachandran, Adriana Lleras-Muney, and Kimberly Smith ${ }^{32}$ and we obtained the malaria data from the NBER. We used these data to create state-specific pre-sulfa rates for each disease by averaging the mortality rate between 1930 and 1936. In section 3 of the text we argue that pneumonia dominates in the combined category and that declines in influenza and pneumonia are largely driven by declines in pneumonia. We also used race specific state mortality data which Adriana Lleras-Muney generously provided. They are from yearly US Vital Statistics volumes (http://www.cdc.gov/nchs/products/vsus.htm).

Socioeconomic Characteristics and Infrastructure Variables_- State time series data on logged state per capita income were taken from the Bureau of Economic Analysis website (http://www.bea.gov/regional/spi/). Data on the number of schools, doctors, hospitals, and educational expenditures per capita were taken from Adriana Lleras-Muney's website (http://www.econ.ucla.edu/alleras/research/data.html). These data were originally collected from various volumes of the Biennial Survey of Education (schools and expenditures) and the American Medical Association's American Medical Directory (doctors and hospitals). We used linear interpolation for each state to calculate education and health infrastructure values for 1940-1943, as Lleras-Muney's data was only collected through 1939. For state per capita health expenditures, we used data collected by Sylla, et al from various reports from the US Census bureau. For the study period of interest, this data source had information for 1932, so we used data for that year, interacted with post in our regression models. This data can be found at:

http://www.icpsr.umich.edu/icpsrweb/ICPSR/studies/6304? archive=ICPSR\&q=6304

${ }^{32}$ http://www.nber.org/data/vital-statistics-deaths-historical/), (http://www.aeaweb.org/articles.php?doi=10.1257/app.2.2.118) 